Portland State University

PDXScholar

$5-1975$

\title{
Implications of American Missionary Presence in 19th and 20th Century Iran
}

Linda Colleen Karimi

Portland State University

Follow this and additional works at: https://pdxscholar.library.pdx.edu/open_access_etds

Part of the Islamic World and Near East History Commons Let us know how access to this document benefits you.

\section{Recommended Citation}

Karimi, Linda Colleen, "Implications of American Missionary Presence in 19th and 20th Century Iran" (1975). Dissertations and Theses. Paper 1827.

https://doi.org/10.15760/etd.1826

This Thesis is brought to you for free and open access. It has been accepted for inclusion in Dissertations and Theses by an authorized administrator of PDXScholar. Please contact us if we can make this document more accessible: pdxscholar@pdx.edu. 
AN ABSTRACT OF THE THESIS OF Linda Colleen Karimi for the Master of Arts in History presented May 2, 1975.

Title: Implications of American Missionary Presence in 19th and 20th Century Iran.

APPROVED BY MEMBERS OF THE THESIS COMMITTEE:
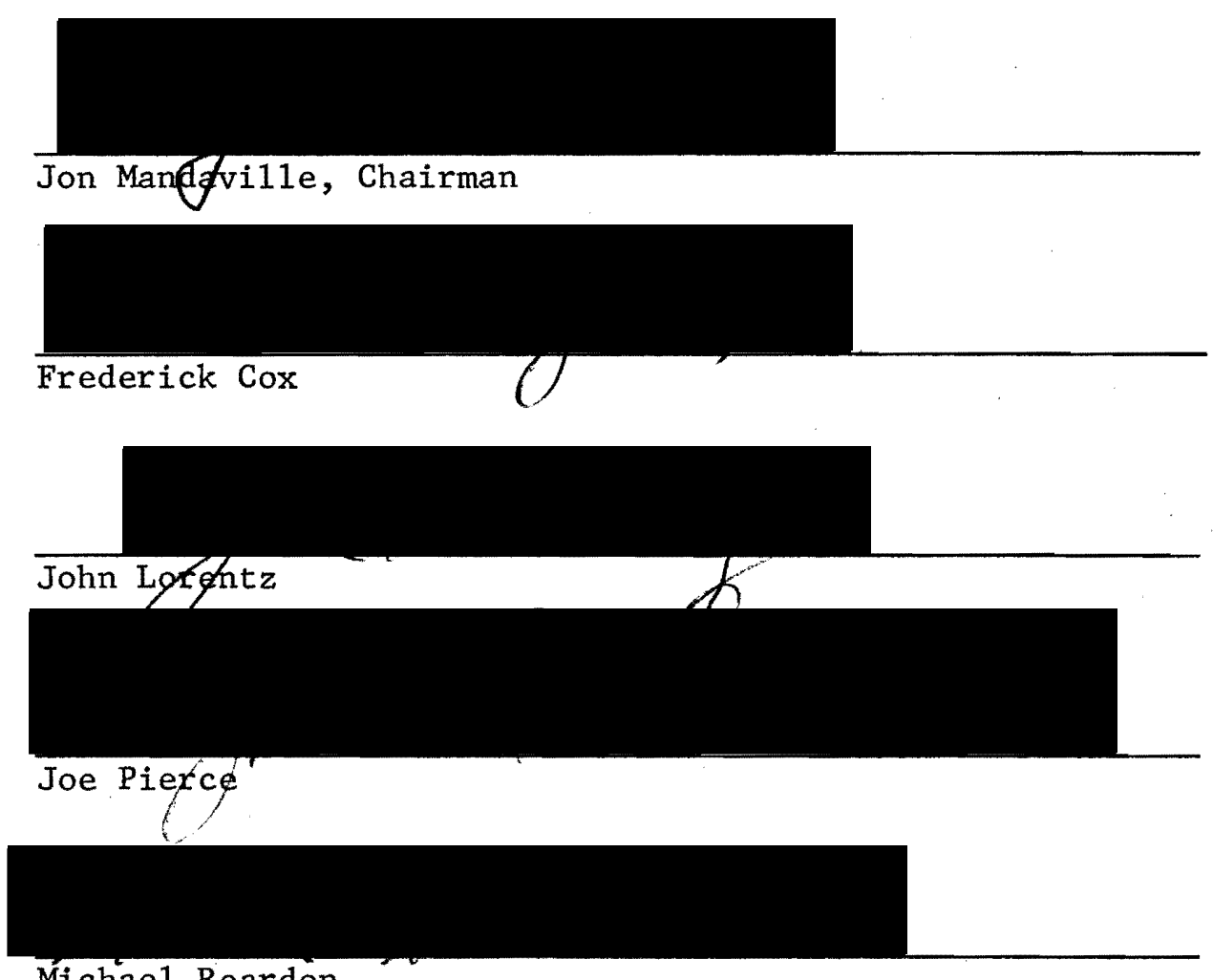

Michae1 Reardon

American missionaries to Iran exerted 1ittle influence in the area of religion, rather their impact was in education and medicine. Two decisive factors involved in their success were the awakening of Iran to the advances of Western technology and the 1imited scope of indigenous opportunities in the fields of learning and medicine. Their work in Iran was, however, hampered by opposition from those elements wishing to 
retain the status quo. In spite of such reactions, they were able to maintain their positions in Iran for approximately one hundred years. It was the advent of the Pahlavi dynasty which initially limited their work and eventually assimilated it into the national system. The establishment of a strong central government, free of foreign controls, virtually brought to a close the work of the American missionary educators and doctors in Iran.

In researching this topic, I found the material available was limited. Many of the sources were written by former missionaries or 19th century travellers to Iran, providing essential information. It was imperative to keep in mind that the personal involvement of the individuals could easily obstruct objective treatment. Yet such works were important in furnishing excellent firsthand information and impressions.

An interesting addition to the published materials, and a very helpful source, was the correspondence I had with a number of former missionaries and missionary students. Their letters provided insight not available from other sources and also gave reflections on the missionary role with the advantage of hindsight. They contributed a great deal and were also helpful in suggesting other individuals and sources to consult.

Unfortunately it was impossible to obtain the materials available in the New York Archives of the American Board of Commissioners for Foreign Missions. Use of such materials would no doubt have been beneficial. Additionally, a number of former missionaries now reside in Westminster Gardens in Duarte, California. If arrangements could have been made to interview them personally a great deal could have 
been learned. As this was not possible, correspondence was substituted. Based on the sources consulted and materials available I feel that a convincing argument can be made for the impact of American missionaries in the areas of education and medicine during their century of mission work in Iran. 
IMPLICATIONS OF AMERICAN MISSIONARY PRESENCE

IN 19TH AND 20TH CENTURY IRAN

\author{
by \\ Linda Colleen Karimi \\ A thesis submitted in partial fulfillment of the \\ requirements for the degree of
}

\title{
MASTER OF ARTS \\ in \\ HISTORY
}

Portland State University

1975 
TO THE OFFICE OF GRADUATE STUDIES AND RESEARCH:

The members of the Committee approve the thesis of Linda Colleen Karimi presented May 2, 1975.

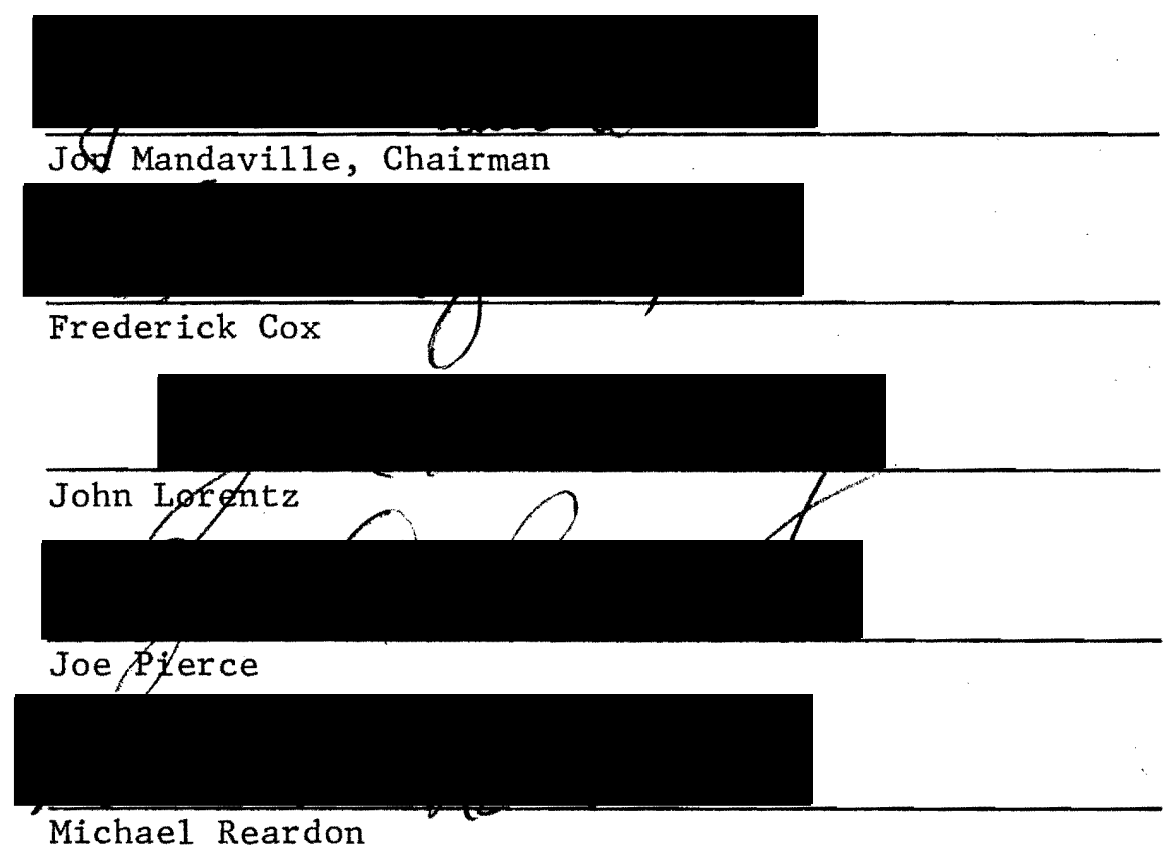

APPROVED :

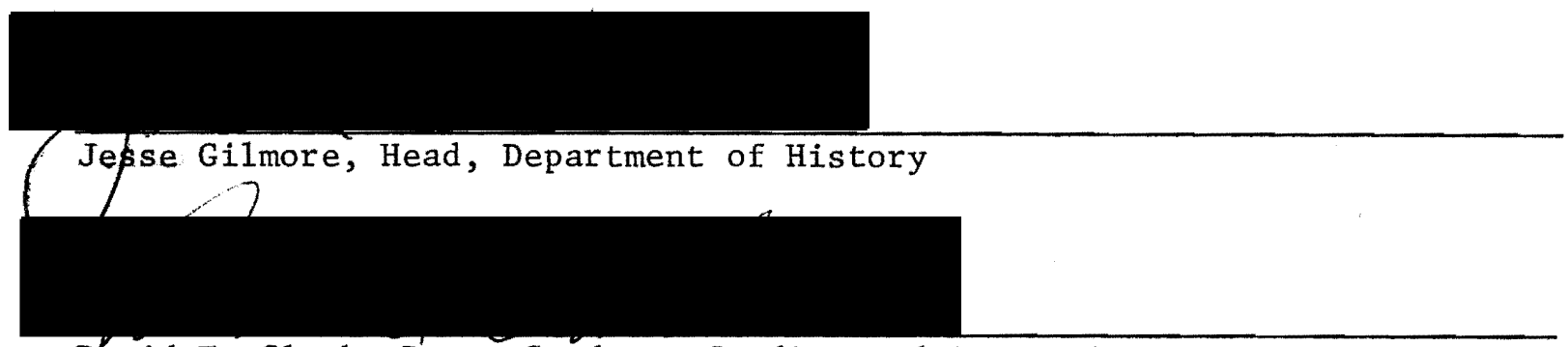

David T. Clark, Dean, Graduate Studies and Research

May 2, 1975 
TABLE OF CONTENTS

PAGE

INTRODUCTION . . . . . . . . . . . . . . . . . 1

REVIVAL OF EVANGELISM . . . . . . . . . . . . 3

EARLY YEARS OF THE AMERICAN BOARD OF COMMISSIONERS FOR

FOREIGN MISSIONS . . . . . . . . . . . . . . 6

THE NESTORIAN CHURCH IN IRAN . . . . . . . . . . 8

COMPARISON OF MISSIONARY EXPERIENCES IN IRAN AND

THE OTTOMAN EMPIRE . . . . . . . . . . . . . . 12

OTHER EDUCATIONAL OPPORTUNITIES IN IRAN

U1ama . . . . . . . . . . . . . . . 15

Government Schools . . . . . . . . . . 17

Private Local Schools . . . . . . . . . . . 19

MISSIONARY EDUCATION . . . . . . . . . . . 22

MEDICAL MISSIONARIES . . . . . . . . . . . 32

BEGINNING OF MISSIONARY PROBLEMS . . . . . . . . . 43

DIVISION OF THE MIDDLE EAST MISSIONARY FIELD . . . . . . 48

OPPOSITION TO MISSIONARY WORK

Nestorian Hierarchy . . . . . . . . . 50

Government-Ulama Relations .......... 53

The Ulama............. . . . 55

The Government . . . . . . . . . . . 57

ESTABLISHMENT OF DIPLOMATIC RELATIONS . . . . . . . 59

MISSIONARY POLITICAL INVOLVEMENT . . . . . . . . 63 
RESTRICTIONS IMPOSED BY REZA SHAH

Change of Dynasty - Qajar to Pahlavi... . . . . 68

Similar Measures of Abdul Hamid . . . . . . . 69

Restrictions on Education in Iran . . . . . . . 70

Indigenous Private Schools . . . . . . . . . 75

Restrictions on the Ulama ............. 75

Limitations on Medical Work . . . . . . . 77

THE FINAL CHAPTER . . . . . . . . . . . . . . 81

SOURCES CONSULTED . . . . . . . . . . . . . 89

APPENDIX

American Missionaries to Iran Prior to 1870 . . . . . 96

American Missionaries to Iran after 1870 . . . . . 97

Mission School Graduates in Iran . . . . . . . 106

Partial Listing of Faculty of A1borz College . . . . 110 
INTRODUCTION

When dealing with missionary endeavors abroad most writers tend to concentrate on the evangelical aspect. However, missionaries have played a much more extensive role than this. In the case of Iran, the evangelical impact of the missionary effort was minimal in comparison to both the medical and educational branches of their work. In spite of their original intent of revitalizing the native Christianity, it was through their educators and doctors that the missionaries had their greatest influence on 19 th and 20 th century Iran.

For centuries Iran had been relatively isolated from the outside world and its advances. Such conditions were to change as other countries acquired an interest in Iran. The British viewed Iran as a buffer for their Indian Empire and the Russians sought territorial gains. As a matter of fact, it was the Perso-Russian Wars (1813 and 1827) that suddenly awakened the Iranian government to the power of the Western nations. In order to compete, in order to survive, Iran, too, had to master Western technology.

Yet this transition was to require almost a century. The 19 th century witnessed the beginning of change within Iran and the American missionaries played a role in this process. Because of the lack of educational opportunities within Iran, as well as the need for medical care, the missionaries provided such services until the government was able to do so. They maintained this role for approximately one hundred years, during which time they made innumerable contributions. 
However, these contributions were not made without opposition. The introduction of this new force infringed upon the status quo. Many Iranians felt their positions threatened. The missionary presence aroused the antagonism not only of the hierarchy of the local Christian churches, but also local officials, the Muslim ulama and the Persian government. This conflict was further intensified by the fact that the Christian minorities began to look to the missionaries, rather than. their own leaders, to mediate their disputes. Thus, in addition to their role of educator and doctor, the missionary also became an arbitrator on behalf of the Nestorians.

In tracing the development of the American missionary activities in Iran from their origins in 1834 through the year 1941, it becomes apparent that this was a century of changing political climate and social conditions within the country. The year 1941 is not an arbitrary date but was chosen because at this point the government had taken over a11 foreign operated schools and had established laws that 1imited the medical practice of the missionaries. Such measures are indicative of the effort made by Reza Shah Pahlavi, prior to his abdication in 1941, to consolidate power and decrease foreign control. As a result of the continuing efforts of Reza Shah to concentrate power in his hands, the missionaries' role in education and medicine was absorbed by the state. 
REVIVAL OF EVANGELISM

The ear1y 19th century saw the emergence of a new revival of evangelism both in the United States and on the Continent. The motivating forces behind this wave of missionary spirit were numerous. A significant impetus was no doubt provided by the late eighteenth century explorations. $^{1}$ Though these were conducted in large part by the British one must not forget that the American Revolution was a recent occurrence and the ties between the two countries were still quite strong.

One of the primary bonds between these two countries was religious affiliation. In light of this, the American missionary zeal can be viewed as a counterpart to that of the British. Though the first response of the Americans was towards a cooperative program of assistance in missionary endeavors, the War of 1812 was to nullify any such hopes and the Americans were forced to venture forth on their own.

Yet another factor of considerable importance in the 19th century was the conviction that the Millennium had arrived. That is, the return of Christ was at hand. The religious revival was to concentrate on the conversion of the world and the preparation for the Second Coming. The imminent collapse of both Islam and Catholicism and the conversion and restoration of the Jews were foreseen. Timothy Dwight, president of

$1_{15 \text { th }}$ and 16 th century explorations had been entirely dominated by the Spanish and Portuguese. Being predominantly Catholic nations they had used their power to spread Catholicism. The waning of this power and the appearance of the British provided a resurgence of the Protestant religion. There was a great deal of work to be done in foreign fields to make up for the long time eminence of Catholicism. 
Yale, in 1808 preached that

The ancient establishments, civil, literary, and religious, of the 01d World are, to a great extent, crumbling into ruins. The throne of the Romish hierarch is shaken...the tottering mosque of Mahammedism announces its own approaching fal1.2

The exact year of the beginning of the Millennium was fixed as 1866. It was calculated that the 1,260 years which the Bible stated would be the reign of the anti-Christ was to come to an end in that year. $^{3}$ This was based on the contention that in 606 A.D. the Pope had become a universal ruler and the accompanying belief that this was also the date of origin of the Islamic Empire. Thus the dawning of the Second Coming was near and waited only for a mass conversion to Christianity before it made its emergence.

In addition to the belief in the Millenium, the prevailing 19th century ideas of Manifest Destiny and Social Darwinism played their part in advancing evangelism. Nineteenth century Americans believed that they had been called upon to fulfill a mission. Based on their belief in Ang1o-Saxon cultural superiority, they were convinced of their divine mission impelled by forces beyond human contro1. Another factor which complemented this belief in Anglo-Saxon superiority was Social Darwinism. The survival of the fittest was believed to be the instrument for the evolution of society as we11. Though it may be that Darwin's followers distorted his biological theories into sociological hypotheses, this did provide a focus of thought during the 19th century.

${ }^{2}$ James A. Field, America and the Mediterranean Wor1d 1776-1882 (Princeton: Princeton University Press, 1969), p. 85.

${ }^{3}$ Ibid., p. 85. 
The sudden evangelical spirit of the 19th century was also a reaction against certain elements. For example, the excesses of some promoters of Jacobinism in France during the French Revolution alarmed conservative clergymen in England and the United States. These men believed that there was a vast conspiracy of atheists, deists, and liberals of other varieties who were hoping to overthrow the Christian religion and to substitute for it the worship of the goodness of reason. The immediate objectives of these anti-Jacobinists were the conversion of the Jews and their restoration to Palestine in accordance with Scripture prophecy, the salvation of the heathen, and the routing of infidelity. 
EARLY YEARS OF THE AMERICAN BOARD OF

COMMISSIONERS FOR FOREIGN MISSIONS

As a natural outgrowth of this ardent religious revival, new seminaries were established in the United States and the first missionary group to go abroad was among the incoming students. One of the most notable seminaries for purposes of studying the development of missions to Iran is Andover Theological School. At the request of a number of its students, ${ }^{4}$ in June of 1812 the General Assembly of the State of Massachusetts agreed to the chartering of the American Board of Commissioners for Foreign Missions (ABCFM). Only two years after its establishment, the Board was to send two missionaries to India. Lest it be felt that their endeavors were limited to this area, it should be pointed out that missionaries were sent to Ceylon (1816), Tennessee (1817, among the Cherokee Indians), Hawaii (1820), Turkey and the Near East (1820-21), China (1830) and Africa (1834). The original composition of the Board was Congregationalist, but members of the Presbyterian and Dutch Reformed Church were later added until such time as they could establish their own boards.

It is important to note that the Board was financed by private funds and received no government support. This self sufficiency was viewed as advantageous since it freed the Board from undue government pressures and alleviated problems which might arise concerning the

${ }^{4}$ Joseph Grabi11, Protestant Diplomacy and the Near East; Missionary Influence on American Policy 1810-1927 (Minneapolis: University of Minnesota Press, 1971), p. 5. 
presence of government agents in the guise of missionaries. However, with the closing of many foreign missions in the twentieth century some missionaries were subsequently engaged in U. S. government service. 5 In very few instances were these simultaneous appointments though this did not lessen the accusations by those who felt missionaries had shifted their service from Christ to Caesar.

The first missionary endeavor in the Levant occurred in 1820 when P1iny Fisk and Levi Parsons were sent to Smyra and later travelled to Jerusalem. This was the land which had been the cradle of Christianity and Judaism alike. Yet it had also been the birthplace of another religion, Islam, and it was this religion which had thrived and endured. It was soon found impossible to attempt conversion of the Muslims so a decision was reached to concentrate attention on revitalizing the native Christian population.

5

Dr. Walter A. Groves began his career in Iran as a member of the missionary school, Alborz College, and left in 1940. He 1ater returned to Iran to head up the Technical School in Abadan associated with the oil companies and later worked with the university in Shiraz.

$\mathrm{Dr}$. F. Taylor Gurney was originally a faculty member of Alborz College in Tehran. He later worked as a cultural attache of the American Embassy in Tehran. Until his death in 1974 he was an advisor to the Iranian Embassy in Washington, D. C. 
THE NESTORIAN CHURCH IN IRAN

The Nestorian Christians had survived in a predominantly Muslim environment for over a thousand years. The Nestorian Church dates from the 5 th century at which time it refused to accept the decrees of the Counqil of Chalcedon (451 A.D.) which it felt inadequate to safeguard the distinction between the divine and human nature of Christ. The headquarters of the Nestorian Church were in Mesopotamia and from the 8 th century onward the Nestorians carried out an intensive missionary expansion through Central Asia as far as China. However, changes in the political situation eventually proved unfavorable to this extensive work and it gradually collapsed.

Since the 15 th century Timurid invasion of western Asia, the Nestorians had gradually been displaced from the plains and central cities of Persia, Mesopotamia and Kurdistan to the only remaining places of safety, the Hakkiari mountains extending between Lake Urumia and Lake Van. Their mountainous country, thus situated part1y in Azerbaijan and mainly in Kurdistan, consisted of frontier territories between Iran and the Ottoman Empire.

Located between two Muslim states and surrounded by the fierce Kurdish and Yazdee tribes, they led a precarious existence for centuries and were segregated from civilization and the outer world. In their long seclusion they fell prey to ignorance and lost their ancient tradition of theological scholarship. Ritualism became the distinctive feature of their religious practices. 
In their struggle for survival, the leadership of their tribes came to be concentrated in the family which gave them their patriarch (Simon or Shimun). The patriarch grew to be not only their religious head but also a kind of theocratic prince to whom they resorted for arbitration in secular as well as religious matters. The position was an extremely important one and developed into a hereditary institution.

Since the patriarchs remained celibate, the crown usually passed from uncle to nephew. That system, which in all probability worked satisfactorily during the early generations, had disastrous results in the long run as the patriarchal throne occasionally devolved upon children under the influence of their mothers or older sisters who handled the state affairs of the community. Since there was no special training provided for this position, the patriarch had only to be able to perform the simplistic rites and utter the prayers.

For centuries the only approach to the Nestorians from the outside Christian world came from Rome. Until the dawn of the 19 th century the Nestorians remained in their static existence and the nations of the West were unaware of their presence.

Then suddenly came the rediscovery of their little community. This occurred when Claude James Rich, then Resident of the British East India Company in Baghdad, visited the ancient site of the Biblical city of Nineveh in 1820. His report (Narrative of a Residence of Koordistan and on the Site of Ancient Nineveh, London, 1836) on the area excited all types of people, both scholarly and missionary, in England and America. He reported of the Assyrians (Nestorians) "who still conversed in a language similar to that spoken by Jesus and whose peculiar form of Christianity called for study and sympathy." 
Some of the rites and 1iturgy of the Nestorian Church indicated certain similarities with Protestantism. Missionaries became aware of these resemblances and felt that these were the Protestants of the East. While holding the Virgin Mary and the Cross in great reverence, Nestorians objected to the use of the word "mother of God" and also refrained from installing the crucifix in their churches. Though icons and images had no place in either the church or home of a Nestorian, they nevertheless treasured saints' relics.

Perhaps the most interesting feature of their Church was its highly liturgical services. This is not based solely on the antiquity of its origins, but also the fact that the Nestorians in their seclusion retained primitive forms without exposure to the scholarly tampering of theologians.

Like the Protestants the Nestorians rejected the idea of purgatory though they prayed for the dead. They were also sparing with the celebration of the Holy Eucharist, which was considered a very special function, not necessarily associated with each Sunday liturgy. Fasting was required prior to receiving the Eucharist although confession was not generally a requirement for participation.

The form of Nestorian Christianity which has just been described is somewhat illusionary. This is the religion as an ideal. Practices had become rather lax and intertwined with superstition. This everyday practice was the Protestantism with which the missionaries were to deal. The reaction of the missionaries is interesting. In an early impression recorded in his book, Justin Perkins refers to the Nestorians as "degraded" and their religion as a "revolting form of Christianity." 
To Perkins the fasts of the Nestorians amounted to little more than a senseless routine of forms "and their prayers, we fear, are a chattering noise." 6 He also wrote that he did not know what "more artful contrivance Satan could have invented, as a substitute for the pure religion of the Gospel, than he had furnished in the fasts of the oriental churches." 7 Though such statements seem harsh, it is not so strange when one recalls the religious zeal of the missionaries. They had hoped to reawaken the former missionary zeal of these people but they had no idea of the state of the religion. They were just beginning to realize that this was not Protestantism as they knew it.

${ }^{6}$ Justin Perkins, A Residence of Eight Years in Persia Among the Nestorian Christians (New York: M. W. Dodd, 1834), p. 163.

${ }^{7}$ Ibid., p. 165. 
COMPARISON OF MISSIONARY EXPERIENCES

IN IRAN AND THE OTTOMAN EMPIRE

It has already been mentioned that the missionary efforts in the Ottoman Empire preceeded those in Iran. Because of the close geographic proximity of these two nations consideration should be given to the possibility of similar experiences. It will be seen, however, that although their approaches were similar, with emphasis on education, their acceptance differed because of existing conditions within the two countries.

The main distinction between missionaries to the Ottoman Empire and Iran was their status. The very fact that the United States estab1ished an American legation in Constantinople in 1831, 50 years prior to establishment of U.S./Iranian diplomatic relations, is an important factor. Such relations gave an assurance of protection which was absent in Iran. Additionally, the millet system operated in the Ottoman Empire served as further protection of the rights of the American citizens within the Empire. In Iran, on the other hand, the Americans were forced to rely for protection on both the British and Russian embassies, which frequently had the disadvantage of associating the missionaries with British and Russian policy.

American trade relations with the Ottomans, relations which were non-existent in Iran throughout the 19 th century, were also important

8

Though the American missionaries in Iran were in relatively close proximity to their counterparts in the Ottoman Empire, poor communications and bad roads placed them at some distance. The trip between Erzerum and Urumia took approximately two weeks and covered 500 miles. 
in dictating events. In this case there was a lobbying force within the United States, possessing vital interests within the Empire and consequently having a vested interest in American policy in the area.

Also of significance was the fact that missionary work in Turkey in the 1830's coincided with Mahmud II's efforts to introduce Western reform. This created a much more favorable environment than that confronting the missionaries to Iran.

In spite of differences in acceptance within the community, the missionary experience in Turkey had shown that in order to modernize and ensure continuation of reform it was first and foremost imperative to educate the populace. Though evangelization gathers men into churches, "education secures the permanence of those institutions which evangelization calls into existence." 9 Therefore, shortly after the arrival of Justin Perkins and his wife in Urumia in 1834, a mission school was established for the Nestorian Christians of the area. Perkins also immediately engaged a tutor for Syriac, the native tongue of the Nestorians in Iran.

Before actually dealing with the education provided by the missionaries, it is important to understand the significance of education as a vehicle for proselytizing. One of the major advantages of education is that it affords a direct means of approach to the people. Though most were unwilling to accept the new religion, the education offered was enticing. Additionally, the concentration on the young ensured a constituency for the future. It was discovered that the older generation was tied to tradition, whereas the youth were receptive to

9 James L. Barton, Educational Missions (Student Volunteer Movement for Foreign Missions, 1913), p. 3. 
new ideas and innovation. Another important factor, to be discussed later in greater detail, was the fact that local education was either non-existent or unsatisfactory. Finally, and perhaps most significant, was the fact that as literate men and women, the missionaries were able to acquire standing and influence. This fact no doubt accounted in part for the opposition from the ulama. Aside from their religious function, the ulama's domination of literacy within Iran had assured them a position in society. With the advent of the missionary educators they were forced to relinquish a part of this monopoly. 
OTHER EDUCATIONAL OPPORTUNITIES IN IRAN

U1ama

Other than mission schools, the educational opportunities in Iran were limited in number and scope. As previously mentioned, education had been controlled almost entirely by the ulama. Both the makhtab (elementary school, primarily Quranic) and the madresa (college of religious teaching) were controlled by the religious class.

The makhtabs, under the direction of the mullahs, were totally free of governmental or professional control. In cities the akhund often simply opened a makhtab where the neighborhood needed and could support one. The tuition fees were not standard, and were arranged privately between the akhund and the parent. Wagner, writing in 1856, says that wealthy students paid one sahedgeran (19 pence) per month and the poor paid one abbas ( 5 pence) to the mullah. ${ }^{10}$ Since this form of teaching supplied a major source of income as well as prestige for many lowerranked members of the clergy, there were numerous makhtabs in the country.

The children usually began their education with a mullah at the age of seven and continued to receive instruction for as long as they were left in his care. There was no established twelve year program. Those children sent to the makhtab, however, did not enter on the basis

$10 \mathrm{Dr}$. Moritz Wagner, Travels in Persia, Georgia and Koordistan; with Sketches of the Cossacks and the Caucasus (London: Hurst and B1ackett, 1856), p. 108 . 
of wealth alone, but had to show ability. According to the cultural traditions of Islamic Persia, some people are gifted and others are not, and it is useless to educate the unfit. ${ }^{11}$ Thus the highly selective process that operated, although to a large extent dictated by economic considerations, was also determined by the talent of the pupils. Furthermore, owing to religious and social restrictions, girls were excluded from any organized education. Perhaps these circumstances - educational discrimination against the poor, the less able, and girls - were in part responsible for the success of the mission schools.

The subjects taught in the makhtab indicate the static nature of culture and society in 19th century Persia. Ability to read and write, with particular attention to good penmanship, were the first objectives. The pupil then began a long process of memorization. The shi'ah catechism, a good deal of poetry, a standard Persian-Arabic dictionary in verse form, known as the nisab, some Arabic grammar and vast portions of the Quran itself were diligently memorized. As mentioned there were no set number of years for attending a makhtab; therefore, when the pupil had learned what the akhund had to teach he ceased to attend.

Beyond the makhtab there were no institutions for general education. Secondary schooling was entirely on a private tutorial basis. Painstaking attention to calligraphy, a thorough study of classical literature (Qu1istan, Jama Abbas, Avebeh Janan, Tarikhe Nadir, Tarikhe Moajam) ${ }^{12}$ mastery of Arabic grammar, and very occasionally, the rudiments

11 Amin Banani, The Modernization of Iran, 1921-1941 (Stanford: Stanford University Press, 1961), p. 87.

${ }^{12}$ Ahmad Kasravi, Tarikhe Mashrutiateh Iran (Tehran, 1349 AH), p. 19. 
of logic, mathematics, and music were the subjects taught by private tutors. The tutor was usually a lay scribe rather than an akhund. Sometimes a scholar acquired a reputation for learning and wisdom and eager students gathered at his home to hear him. Unless a pupil intended to go into clerical (religious) life, this was the extent of education.

If he did, however, plan to enter the religious ranks, he would continue his education at a madresa. Gone were the magnificent medieval Islamic universities at Nishapur, Tabriz and Baghdad. The only institutions of higher learning in Iran were the seminaries in Qom and Isfahan, ${ }^{13}$ where the major subjects of study were theological treatises, sectarian tracts, Arabic grammar, rhetoric, incantation and jurisprudence (shari'ah and $\underline{\text { fegh) }}$; some logic, arithmetic, and astronomy were also taught (astronomy, for the regulation of the calendar and the proper observance of the fast and prayers). Though the purpose of these madresas was to train young clergymen, it was not uncommon for students to receive the education and then to pursue an administrative career, a tendency that increased toward the end of the 19th century.

\section{Government Schools}

Following the defeat of Iran at the hands of the Russian forces in the Russo-Persian Wars, there was a growing awareness of the technologi-

13 Joseph Wolff, Missionary Labours: Researches and Missionary Labours Among the Jews, Mohammedans and Other Sects (Philadelphia, 1837), p. 136 states that the principal colleges at Meshed were Goombaz BarekaImam Resa, containing two divisions: College of Mirza Jaafar and that of Mullah Mohammad Bakr; College of Fas1-Khan and College of Haji Hassan. Though no other mention can be found of these "colleges", it is probable that they were also madresas associated with a mosque. 
cal advances being made in the West. The establishment of the Dar a1Funun (Institute of Arts and Sciences) by the government in 1851 was designed with the attainment of military strength in mind. This school was staffed by European instructors and included courses in infantry and cavalry tactics, artillery, engineering, medicine, chemistry, geology, French, English and Russian. ${ }^{14}$ The concentration was clearly on the sciences and the graduates were expected to enter the military or civil services.

Mention is also made of a school opened by the Crown Prince, 15 Muzzaferredin Shah, in about 1880 in Tabriz. In attendance were sixty scholars gathered from the best families of the city. It is probable that this school was not actually a private school operated by the crown prince, but rather a government school opened in 1876 in Tabriz and modelled on the Dar al-Funun (Tehran). ${ }^{16}$ In this school many students prepared for public service and were in turn supported financially by the central government. The medical department had several professors who had graduated in Tehran under European instructors. As a matter of fact, in $1890 \mathrm{Dr}$. W. S. Vanneman, an American missionary physician, was asked to give medical instruction in this school, but was unable to do so because of his other duties. Unfortunately very little information is available on this school so there can be no assessment of its curriculum.

${ }^{14}$ L. P. Elwe11 Sutton, Modern Iran (London: George Routledge \& Sons, 1941), p. 63 .

${ }^{15}$ Samue1 Graham Wilson, Persian Life and Customs - With Scenes and Incidents of Residence and Travel in the Land of the Lion and the Sun (New York: Fleming H. Reve11 Co., 1895), p. 188.

${ }^{16}$ Kasravi, op. cit., p. 18 . 
In completing the discussion of 19 th century government schools, there is reference to a School of Languages (Tehran, 1883), military colleges in Isfahan (1883) and Tehran (1886), and establishment of the College of Political Science (Tehran, 1899 under the direction of the Ministry of Foreign Affairs) and the School of Agriculture (Tehran, 1900 under the directorship of a Belgium). There is also mention of the first government girls' school set up at Chalyas near Kerman in 1897. ${ }^{17}$ The existence of these schools was only briefly mentioned and no further information was available.

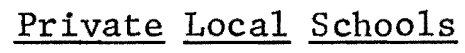

Undoubtedly there were private schools operated by individuals throughout Iran. However, it is very difficult to find information on such schools. In general they were usually ill staffed and the curriculum was very limited. The main concern seems to have been the lucrative business of charging exorbitant fees for very little instruction.

After considerable research only one specific reference to a privately operated school could be found. These were the schools of Roshdia, a Persian citizen, operated in various sectors of Tabriz. Because his were the only schools dealt with in detail, it is difficult to determine how typical they were. There are certain factors which set them apart from the norm, however. Foremost is the fact that Roshdia attempted to introduce "new education" in Iran. Unfortunately there is no explanation of this term. However, the enormous opposition he encountered might have been due to the content of the curriculum.

17 Banani, op. cit., p. 9 believes the date to be 1865 rather than the above-mentioned date of 1897. 
Roshdia was trained in Najaf by his father, a mujtahid and then sent to Istanbu1. He was later sent to Egypt to study in the British Dar a1-Moalemi (School of Education) and then to Beirut to continue his education at the French Dar a1-Moalemi. ${ }^{18}$ He then returned to Iran to begin teaching.

After operating a school in Ervan for five years, Nasir ed-Din Shah visited the school and was so impressed that he asked Roshdia to return to Iran and open a similar school. However, those surrounding the Shah turned him against Roshdia and he later withdrew his support. Roshdia travelled to Tabriz where he opened a school in 1305 A.H. Because of religious opposition to his schools, they were limited in duration. That is, he opened a school for a few months and would then be forced to flee to Meshed. He would later return to open yet another school. At various times he operated schools in the following districts of Tabriz: Sheshgilan, ${ }^{19}$ Kiaban, Bazaar, Charaondab, Nobahr, Laliabad, Masjid a Shakh ol-Islam.

While Muzzaferredin was Crown Prince in Tabriz, Roshdia met him. It was with his financial support and the encouragement of Amin o Dowleh that Roshdia operated his schools in Tabriz until 1314 A.H. Upon ascending the throne in 1315 A.H., Muzzaferredin Shah invited Roshdia to open a school in Tehran. He did so in Kerbalai Abbas Ali. Two of Roshdia's partners also opened two new schools. Additional schools were established by Haj Sayyid Tabatabai. These were

18 "Farhange No Cheguneh Dar Iran Aqaz Shood? Xedmate Roshdieh Be Ma'aref", Amuzesh va Parvarish, XXV, p. 20.

${ }^{19}$ The article cited above indicates that Sheshgilan was a sector of Tabriz; however, Kasravi, op. cit., p. 21 states that this area is located in Tehran. 
Elmia, Eftatahea, Islam and Sharafa Mozaferri. ${ }^{20}$ For reasons not mentioned, control of the schools was taken from Roshdia and he was sent to Qom. Muzzaferradin Shah ordered him to return to Tehran but the prime minister, Ali Asgha Khan Atabek, disliked Roshdia and tried to delay his return to the city. After a brief conflict between Roshdia and Atabek, Roshdia was allowed to continue his educational efforts and had the full support of the Shah.

As previously mentioned, no definition of the term "new education" was provided. However, Kasravi's account indicates 1ittle innovative technique in Roshdia's schools. The students were still sitting on the floor, although blackboards were introduced and there was a change in the teaching of the alphabet. Simpler books were also used to teach Persian in place of the difficult poetry used in the makhtabs. The fact that an attempt was made to keep the students clean seemed to Kasravi to be worthy of mentioning, also. Speaking of the curriculum, Kasravi indicates that there was no introduction of the new sciences of the West.

This then capsulizes the acceptance of "new education" in Iran when introduced by a local Muslim. Unfortunately, there was only sketchy information on the school itself. The emphasis was instead on the resistance which the schools encountered. 


\section{MISSIONARY EDUCATION}

Being aware of the opportunities offered within Iran by indigenous schools, we can now evaluate the education offered by American missionaries. Perhaps the most striking contrast is in the curriculum. 19th century missionary schools offered courses in reading, writing, spe11ing, composition, grammar, singing, geography, arithmetic, and theology with oral instruction in physiology, chemistry, natural philosophy and astronomy. Such broad offerings provided a liberal education and a strong background for those students who later wished to further their education in Iran or abroad.

We have already mentioned that the Iranians were becoming increasingly aware of the Western world and its advances. Feeling that Europe had a great deal to offer, some of the wealthier families preferred to send their children abroad for studies. In order to obtain the necessary educational and cultural skills required, many first sent their children to the mission schools in Iran. This was in spite of the fact that many, being devout Muslims, still considered such schools religiously inferior. The benefits of a good education were just beginning to be recognized.

Though it would be helpful to obtain enrollment figures for the mission schools, this is a difficult task. There is no single source which provides such figures covering the one hundred year span of missionary teaching in Iran. I have, however, compiled figures (see 
page 24) from two major sources ${ }^{21}$ and though undoubtedly incomplete they will provide some idea of the continued expansion throughout the $19 \mathrm{th}$ century. These figures also indicate the increasing percentage of Muslim students enrolled. It is important to keep in mind that these schools 1isted are located in the major cities. In addition to these there were many schools in the outlying areas established with the help of the missionaries and then turned over to the local Christians. A chart indicating enrollment of all mission schools operating in the Urumia area prior to 1860 is also included (page 25). By comparing these figures with those of the mission school in Urumia, we see how many students were enrolled in these small district schools and how inadequate it is to consider only the major city schools in determining enroliments.

The chart also indicates that missionary education in Meshed was not begun until 1925. This being one of the most important religious centers in Iran, the power of the ulama there is unquestionable. The late date of 1925 is indicative of the opposition encountered from the religious leaders. The book Amirzesh va Parvaresh also cites the failure of Roshdia to introduce "new education" in Meshed because of religious conflict. The influence of the ulama and their reaction to missionary work will be dealt with in greater detail later. Suffice it to say that such opposition did exist and was much more strenuous in the case of education than that of medicine.

${ }^{21}$ John E1der, History of the American Presbyterian Mission to Iran 1834-1960 (Literature Committee of the Church Council of Iran, n.d.) and John A. DeNovo, American Interests and Policies in the Middle East 1900-1939 (Minneapolis: University of Minnesota Press, 1963), p. 9 . 


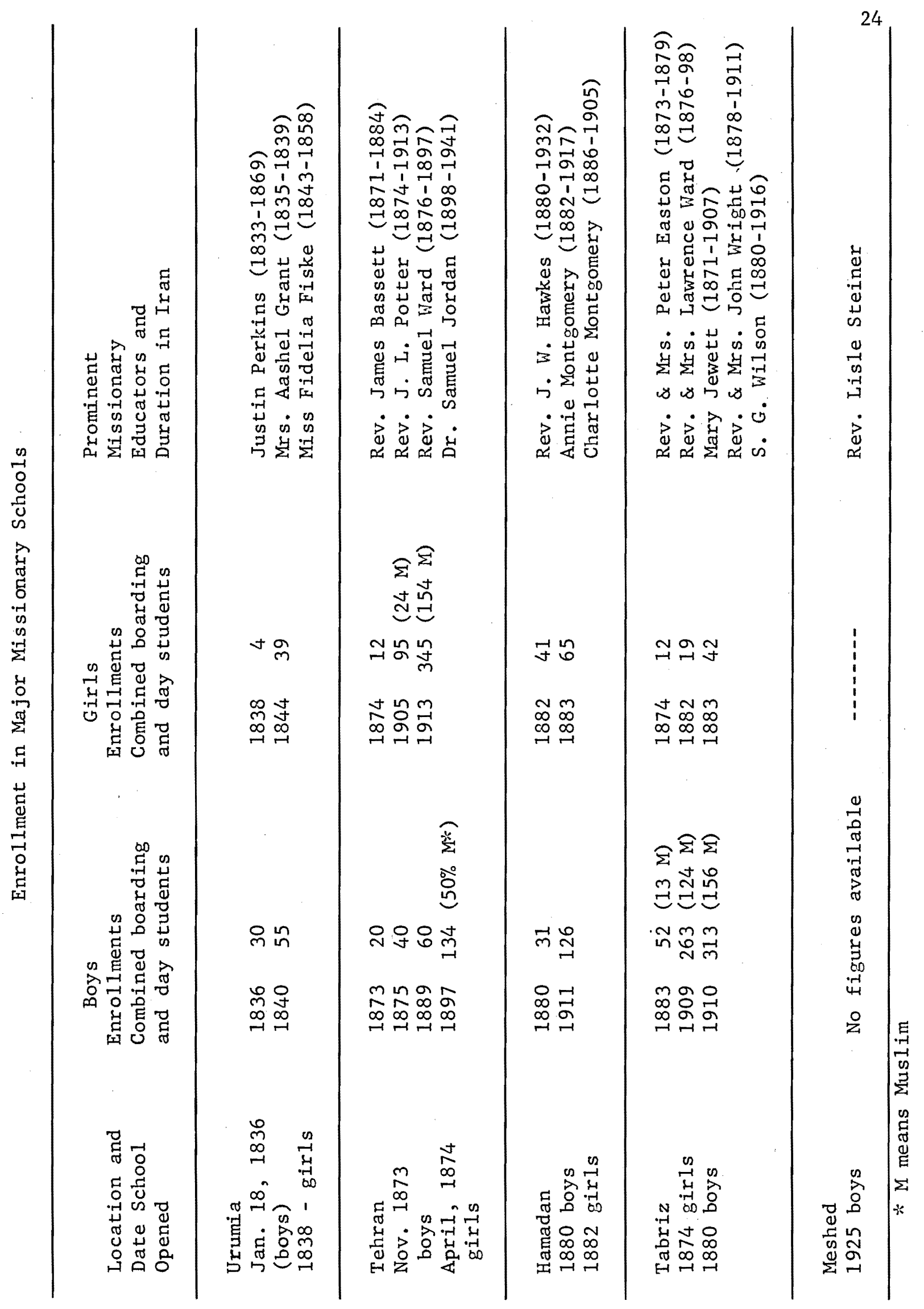




\begin{tabular}{|c|c|c|c|c|c|c|}
\hline YEAR & $\begin{array}{l}\text { NUMBER OF } \\
\text { SCHOOLS }\end{array}$ & BOYS & & GIRLS & \multicolumn{2}{|c|}{$\begin{array}{c}\text { Including Seminary } \\
\text { TOTAL }\end{array}$} \\
\hline 1840 & 17 & 414 & & 25 & & 501 \\
\hline 1841 & 20 & 430 & & 40 & & 516 \\
\hline 1842 & 40 & 635 & & 128 & & 841 \\
\hline 1843 & 44 & 948 & & 117 & & 1142 \\
\hline 1844 & -- & SCHOC & & DISMISSED & THIS & YEAR \\
\hline 1845 & 32 & 382 & IN & ALL & & 462 \\
\hline 1846 & 30 & 441 & & 21 & & 538 \\
\hline 1847 & 36 & 517 & & 91 & & 681 \\
\hline 1848 & 33 & 463 & & 45 & & 578 \\
\hline 1849 & 32 & 473 & & 125 & & 677 \\
\hline 1850 & 35 & 487 & & 166 & & 727 \\
\hline 1851 & 45 & 1023 & IN & ALL & & 1105 \\
\hline 1852 & 60 & 777 & & 261 & & 1128 \\
\hline 1853 & 79 & 990 & & 365 & & 1445 \\
\hline 1854 & 73 & 1092 & & 153 & & 1245 \\
\hline 1855 & 58 & 796 & & 301 & & 1195 \\
\hline 1856 & 53 & 611 & & 283 & & 974 \\
\hline 1857 & 63 & 1200 & IN & ALL & & 1293 \\
\hline 1858 & 54 & 1135 & IN & ALL & & 1222 \\
\hline 1859 & 68 & 936 & & 494 & & 1510 \\
\hline 1860 & 48 & 678 & & 367 & & 1129 \\
\hline
\end{tabular}

Enrollment Figures for Urumia Area Schools $1840-1860^{22}$

${ }^{22}$ Thomas Laurie, Woman and Her Saviour in Persia (Boston: Gould and Lincoln, 1863), p. 297. 
From the early days of missionary work, one of the major concerns was financial support of the students. This has long been a source of disagreement among writers as some see financial assistance as only a lure to attract students to the mission schools. ${ }^{23}$ Admittedly the early students were not from wealthy families. The parents could not afford to send their children to school while at the same time decreasing the family's earning power. As an inducement missionaries initially paid 25 cents per week to their day scholars and, in lieu of this, boarding students received free room and board. Evidently this soon proved unworkable and a nominal fee was charged in accordance with one's ability to pay. If students were unable to make such payments, they were allowed to work their way through school. Former mission students, Professor Yahya Armajani and Mr. William Yoe1, and former instructors Rev. William Wysham and Rev. John Elder, mention the fact that scholarships during the 20 th century were made available on the basis of nine full paying students, enabling a tenth student to attend free of charge.

Because no financial distinctions were made at the mission schools, they served as equalizers in society. There were students of all financial and social levels attending. Each was accepted as an individual on his own merits. Students of the nobility and landholding class, as well as sons of slaves and peasants, were represented. They a11 slept in the same rooms, ate at the same table and did chores assigned to all. Former students and teachers attest to this and indicate that the dignity of labor and worth of the individual were an

23 T. W. Marsha11, Christian Missions: Their Agents, Their Method and Their Results (London: Burns \& Lambert, 1862), II, p. 438; Wagner, op. cit., pp. 256-257. 
important part of the missionary legacy.

It is clear that the mission schools not only provided basic educational skills, but also ushered in Western ideas and values, the importance of which cannot be underestimated. One of the more far reaching ideas introduced by the missionaries was that of change. This was an important tool in ministering to a static society based on tradition.

One of the notable changes, championed by the missionaries, was the role of women. That they could not read or write had been taken for granted. As a matter of fact, education was considered an impropriety and an infringement on female modesty. Upon their arrival in Iran the missionaries found only one women, Heleneh, the sister of Patriarch Mar Shimun, was able to read. This was to change, however, with the establishment of the first girls' school in Urumia in 1838, predating the first such government school by almost sixty years. As a matter of fact, moving ahead to 1962, at the first International Conference of Middle Eastern Women, held in Tehran, over half of the Iranian delegates were graduates of Iran Bethel, a mission school established in $1874 .^{24}$

Certainly the missionary women played an important role in advancing womens' rights. They wore no veil, were shown respect by men, were we11 mannered and educated. As young Iranians attended the mission schools and were sent abroad for study they began to accept this new status for women. Many sought wives who were educated. Thus some

\section{${ }^{24}$ Letter of Rev. William Wysham to writer dated January 23,} 1973. Iran Bethel is the present day Damavand College for Women in Tehran and is now administered by Iranians. 
families, in order to ensure good marriages for their daughters, found it necessary to see to their education. 25

Mission school education did not, however, only pursue intellectual growth of the individual. Character development was also a goal of mission education. Therefore, attempts were made to encourage certain values. For example, there was emphasis on the "dignity" of labor. The Persians had previously considered manual labor to be a demeaning task reserved for servants. We have already noted that in mission boarding schools, students were assigned a variety of chores to perform. Such jobs as sweeping the floors, washing dishes, cleaning chalkboards, or servind meals were a part of a routine school day. Children of all economic levels were required to comply with these rules. Dr. Samuel Jordan, president of the American Boys' School in Tehran (1ater Alborz College), tells of his students setting off with picks and shovels to help in building a soccer field for their school. He mentions the consternation that this aroused from onlookers and the stares and whispers as the boys walked down the street with their tools in hand. It was also Dr. Jordan's students who played an active role in 1917 in food distribution during the famine of that year. Therefore, in addition to the educational skills acquired at the mission schools, we have seen that certain values were instilled. Mission students, looking back on their education, were to point to these values as an integral part of their learning.

Dr. Samuel Jordan has only been mentioned briefly thus far. However, he is one of the better known American missionaries to Iran in ${ }^{25}$ For further information see Ruth Woodsma11's Women of the Near East. 
the field of education. Arriving in Iran in $1398 \mathrm{Dr}$. Jordan took over principalship of the Tehran Boys' School which had been established in 1873 as an elementary schoo1. By 1900 it was a high school with Muslim students comprising $60 \%$ of the enrollment. In 1913 it became a junior college and in 1924 it was granted college status. 26

Dr. Jordan served as principal until the school's closure in 1940. He worked diligently from his arrival to ensure that this school would some day fulfill the necessary requirements to become a college. He felt it imperative that Iranian students be able to attend college within the country. He believed that those educated in western countries often got out of touch with their own countries and lost sympathy for their people and their condition. Referring to the Western educated student, Dr. Jordan says

He too often discards indiscriminately the good and bad of the old civilization and fails to assimilate the best of the West. He loses all faith in his old religion and acquires nothing in its stead. 27

It was Dr. Jordan's intent in the mission schools to adapt Western methods to the needs of the country.

A11 such adaptations were not, however, aimed at academics. One such exception was the introduction of sports. Upon the arrival of the missionaries to Iran, the major sports were wrestling, as exhibited in the Zur Khaneh (House of Strength) and hunting, reserved for the nobility. Along with the introduction of volleyball, soccer and tennis came the idea of cooperation. Students soon learned that cooperation

${ }^{26}$ To provide some idea of the curriculum, a partial listing of Alborz College faculty and their speciality is appended to this paper.

${ }^{27}$ A. C. Boyce, "Alborz College of Teheran and Dr. Samuel Martin Jordan, Founder and President" (mimeographed), 1954, p. 14. 
was as important as competition in sports as we11 as other areas. Mr. William Yoel, a former missionary student, also writes that the first bicycle was brought to Iran by a former missionary school graduate upon his return from Canada.

Though one would probably not think of sports as a major contribution there is much to be said for it. It had the benefit of providing much needed physical exercise and it also served to free Muslim children from certain restrictions placed on their physical activity. Muslim parents had previously considered it undignified for children to be running about. From an early age they were expected to emulate their parents in both manners and dress. This carried through into the 20th century. Boys of we11 to do Persian families wore long, pleated coats buttoned up to the neck and pillbox hats without brims. Both the dress and the parental disapproval dissuaded Muslim children from taking part in active sports. However, as sports became a part of the mission school curriculum, Muslim children were able to participate. This was a welcome addition to the school activities. Eventually sports were also incorporated into the curriculum of government schools.

We have seen that the contributions of the missionaries in education were many and varied. To view the impact of their schools on the country, it is useful to look at their graduates. In reviewing the graduates of the American mission schools in Iran, one finds that many of them were among the leading men of 20 th century Iran. They held positions in government, business, science, banking, medicine and education. In lieu of innumerating all mission school graduates, a partial list of the better known is appended to this paper. It is 
obvious that they constituted only a small percentage of the entire number of graduates. However, because of the positions which they later held they were able to play an important role in the development of 20th century Iran. After the missionaries left the country, their former students were to not only see the benefits of a hundred years of missionary education, but also to make their own contributions. 
MEDICAL MISSIONARIES

Medical work carried out by the missionaries was undoubtedly one of their most enduring contributions. A year after the arrival of Justin Perkins in Urumia he was joined by $\mathrm{Dr}$. Aashel Grant who was to be the first American medical missionary to the area. Though he worked in Iran for only nine years before his death, Grant provided a foundation for medical work that was to endure for the next one hundred years. Grant's attitude played a very important role in gaining the confidence of the people. His desire was to impart his knowledge as well as his medical abilities to the people. From the beginning he avoided competing with the native "doctors". Instead he gave samples of his medicines, hoping that they would emulate his methods. Additionally he lent his instruments to be used as patterns. To ensure that his work would have some lasting effect he also took a native youth and trained him as an apprentice. ${ }^{28}$ This practice was continued intermittently by other medical missionaries and provided able assistants over a period of years.

Though in his use of poultices and bleeding, Grant was only a step or two ahead of Oriental medicine as practiced for hundreds of years, as a surgeon he was much more advanced. One of the major medical problems in Iran throughout the 19 th century was that of eye disease, trachoma and cataracts. The mission doctors were familiar with these

${ }^{28}$ Robert L. Daniel, American Philanthropy in the Near East 18201960 (Athens: Ohio University Press, 1970), p. 63. 
and were able to give relief through surgery. Reviewing missionary records one notes that as many as ten percent of the population were afflicted with this or similar eye ailments.

In addition to trachoma, missionary doctors later discovered and reported hookworm and black water fever in the Caspian provinces. Work was later done on this at the Resht Hospital. The laziness of the people of the north, a result of these diseases, had previously. been blamed on the climate or malaria. It was estimated that fifty percent of the people suffered from these infections. 29

Medical missionaries also provided assistance to lepers in colonies near Tabriz and Meshed. Government allotments were insufficient and provided only money, no medical assistance. Missionaries established medical facilities and brought food and clothing. 30 In 1935 the missionaries were training four young lepers in Meshed as nurses so they could aid in applying dressings.

Though Grant never actually established a hospital during his short time in Iran, he did have a dispensary. Treatment was provided and medicine prescribed. Thus there were clinic services available in addition to the dispensary. However, such services do not constitute a hospital although Messrs. Sutton, Banani and Watson ${ }^{31}$ credit Grant with opening the first hospital in Iran in 1835. Actually the first hospital (mission) was constructed in Urumia in 1882.

${ }^{29}$ Sarah McDowe11, mimeographed paper "A Century of Medical Missions in Iran," (unpublished), p. 13.

30 The Shrine of Imam Reza also provided food and clothing to the leper colonies.

${ }^{31}$ Sutton, op. cit., Banani, op. cit., Charles R. Watson, What Is This Moslem World? (New York: Friendship Press, 1937). 
The native people to whom $\mathrm{Dr}$. Grant ministered had never been exposed to medicine as practiced by the missionary physicians. Their reactions were typical of a people who still believed in the potence of Quranic writings, amulets and herbal concoctions. Dr. J. P. Cochran, writing in 1879 says that the people "bolt at a swallow the medicine prescribed for a week saying it might as well cure at once as to take several days." Maintaining their belief in the necessary balance of the four humors and the distinction between hot and cold foods, the patients might ask "Must the milk be that of goat, sheep, buffalo, ass or cow; and if cow, what must be her color?" According to native lore, milk of a white cow was cold and that of a red one, hot. Such examples provide insight into the medical knowledge and understanding of these people and also emphasize the problems which the missionary physicians encountered in working among them.

There is evidence as early as the time of $\mathrm{Dr}$. Grant that even the Muslim leaders of the community took advantage of the missionary's medical assistance. For instance in January 1835 Grant writes that

For the last few days there have been very few Mussulman patients, on account of their great feast, but today they came as numerous as usual, not withstanding a severe snowstorm...Visited the wife of one of the head mollahs of the city who is dangerously sick. She is the governor's sister.

However, reaction by the religious leaders varied greatly. Some would preach against the doctors saying they were unclean and knew nothing of proper diets. In spite of such accusations the number of patients seen by the missionary doctors continued to increase. The people were beginning to realize that these missionaries had something of benefit to offer. Though almost all denied their religious offerings, many took advantage of their medical knowledge. 
In $1882 \mathrm{Dr}$. Joseph P. Cochran built Westminster Hospital, the first regular, fully equipped hospital in Persia located in Urumia. Yet even with a hospital, conditions under which physicians worked were still extremely difficult. There was no pharmacist in the area and the doctor had to compound his own medicines. He had no orderly, no nurses and often no colleague. Servants and even school boys were used to administer chloroform. During the operation the doctor was required to take the patient's pulse, listen to breathing and select his own instruments. On completing the operation, the doctor would assist in carrying the patient back to bed. Such conditions would have been inconceivable to newly practicing doctors in many other areas of the world. Certain1y those who arrived in Iran to practice medicine quickly learned to improvise.

Five years after the opening of Westminster Hospital land was purchased in Tehran for a second American missionary hospital. The Shah himself issued a farman for its erection. Initially there were stipulations placed on the hospital which were unacceptable to the missionaries. A muezzin was to be appointed to look after the spiritual welfare of the patients and no women were to be admitted. The Prime Minister, Amin o Dowleh, assured the mission that the farman was not binding, removed the objectionable conditions and took upon himself al1 responsibility.

To place the medical work of the missionaries in perspective it is helpful to see what the local Iranian people and government were doing in the area of medicine during the 19 th century. Sutton says that in 1877 the first Persian hospital was opened. 32 However, no other ${ }^{32}$ Sutton, op. cit., p. 128 . 
of the winter.

Medicine was practiced by hakims or herb doctors who still followed the medical system of Avicenna. They prescribed herbs, laxatives and special diets in great detail. Constitutions, diseases and food were classified as either hot or cold and it was necessary that prescriptions be given accordingly.

Many medical procedures were being performed by barbers and midwives. The former were called in for incising abcesses and pulling teeth. The midwives were superstitious and frequently untrained in proper delivery methods. For example, an old shoe was tied to the cord in a delayed third stage of labor; a large knife and onion were kept under the pillow of the new mother to prevent the "aw1" from snatching the liver of the newborn baby. ${ }^{34}$ As infants were not bathed until taken to the public bath after several weeks or even months, tetanus from infected cords killed many newborns.

Relying solely on the local medical practices of the Iranians, it was difficult to treat even the simpler injuries, e.g. broken bones, wounds. The problem of serious disease was one that could not be dealt with by the use of herbs or charms. In addition to such inadequate treatment, certain conditions actual1y contributed to disease. We have already mentioned the prevalence of superstition. $\mathrm{S}_{\mathrm{u}} \mathrm{ch}$ beliefs made it difficult and at times impossible to provide treatment. The sanitary conditions within Iran also played a part in the spread of disease, often in epidemic proportions. Although people were advised to eat only cooked foods, to boil drinking water and to wash their hands

${ }^{34} \mathrm{R}$. E. Hoffman, Pioneering in Meshed, The Holy City of Iran: Saga of a Medical Missionary (n.p., 1971), p. 24 . 
after handling the sick, few understood the reasons. They could not comprehend the cause-effect relationship between germs and disease. The public baths also furthered the spread of illness as the water was seldom changed, only replenished, and thus served as a breeding ground for bacteria. An attempt made to require changing the water once a month failed.

Yet even in the face of such deplorable conditions, the mission doctors found it difficult to introduce their new methods and procedures. As they were new to the area people were still suspicious of them. Because of this they had to be cautious in their approach. For example, in accepting patients for surgery the missionaries preferred to accept only those who had a good chance of recovery. It was felt that if a patient died while in a Christian hospital, the people might force the missionaries to leave.

Another matter of concern was the aftercare provided for the patients. It was folly to think that once they returned home they would get the proper care required. The people did not understand the possibility of infection or complications caused by inadequate care. Such concerns frequently led to refusals to operate unless patients agreed to remain in the hospital until complete recovery was gained. In spite of these restrictions, the missionary doctors continued to work among the people and gain their confidence.

As mentioned, doctors often worked alone or with only one assistant. Under such conditions their workloads were incredible. Dr. R. E. Hoffman, writing of his medical work in Iran during the early $1900^{\prime} \mathrm{s}$ states that "During April I saw from 126 to 278 patients a day, three days a week, and did 157 operations, with only my local trained helpers." 
This is not an isolated incident, and had occurred throughout the 19 th century, beginning with Dr. Grant.

In addition to work within the cities, there was also a practice of medical itineration. A physician would go into the field for a six week period and set up temporary dispensaries and hospitals. Most such itineries worked out of the Tehran and Meshed stations. This provided medical assistance to those who rarely left their villages. Eventually this practice was discontinued as improved roads enabled people to come to the city more easily and as increasing demands within the city made it impossible for the physicians to get away.

We have already discussed the establishment of dispensaries and hospitals and the training of assistants. Following these accomplishments, the missionaries began a training program for nurses. This was first undertaken in 1916 in Tehran with four women graduates of the Tehran Gir1s' School. They were instructed for nine months in caring for the sick in the wards, preparing and sterilizing dressings, arranging the operating room and selecting instruments for operations. Though the work began in Tehran, it spread quickly to the other missionary stations.

In addition to their missionary duties, the physicians were often called upon in other capacities. For example in $1883 \mathrm{Dr}$. Torrence agreed to a request by the Shah to accompany the new Persian Envoy Extraordinary and Minister Plenipotentiary to Washington. In addition to this, missionary doctors frequently provided medical services for the Shah and his family. There seems to be some disagreement over whether missionary physicians actually served as court physicians. According to former missionary educator, Edwin Wright, Dr. John G. Wishart was 
personal physician to the Shah and Dr. W. S. Vanneman served in the same capacity to the Crown Prince in Tabriz. Writer, Robin Waterfield, also mentions that in $1892 \mathrm{Dr}$. George $\mathrm{W}$. Holmes became personal physician to the Shah. Yet Mrs. Sarah McDowe11, former missionary to Iran, indicates that both Dr. Vanneman and Dr. Holmes were asked to become court physicians but declined to do so. This may not be a difference of opinion, but rather one of semantics. Just what is entailed in the term "personal physician" or "court physician" is unclear. It is likely that the missionary physicians acted in consultation with court physicians and were themselves available to the court as needed.

In reviewing the many facets of medical missionary work in Iran, attention has been given to the conditions within the country and the attempts made to improve them. Though a good deal was accomplished, it was not without great hardship on the part of the missionaries. The misfortunes which they endured cannot be overlooked. Many of the missionaries buried their husbands, wives and children while serving in Iran. Among the early missionaries to Iran, Justin Perkins himself lost six of his children while in Iran and Dr. Grant's wife (age 25) and twin daughters died after only four years in the field. Yet, in most cases the missionaries did not abandon the field. Justin Perkins remained in Iran for twenty six years, until his death in 1860 and Dr. Grant returned to the United States only briefly to place his four year old son in a foster home and then returned to continue his work among the mountain Nestorians until his death in 1844. Many of the later missionaries died of cholera, typhus, typhoid, or smal1pox while ministering to the sick. Epidemics were frequent in Iran and difficult to control. Dedication and endurance were definite traits 
of the medical missionaries to Iran. The chart on page 42 indicates the long number of years that most medical missionaries served in Iran. 


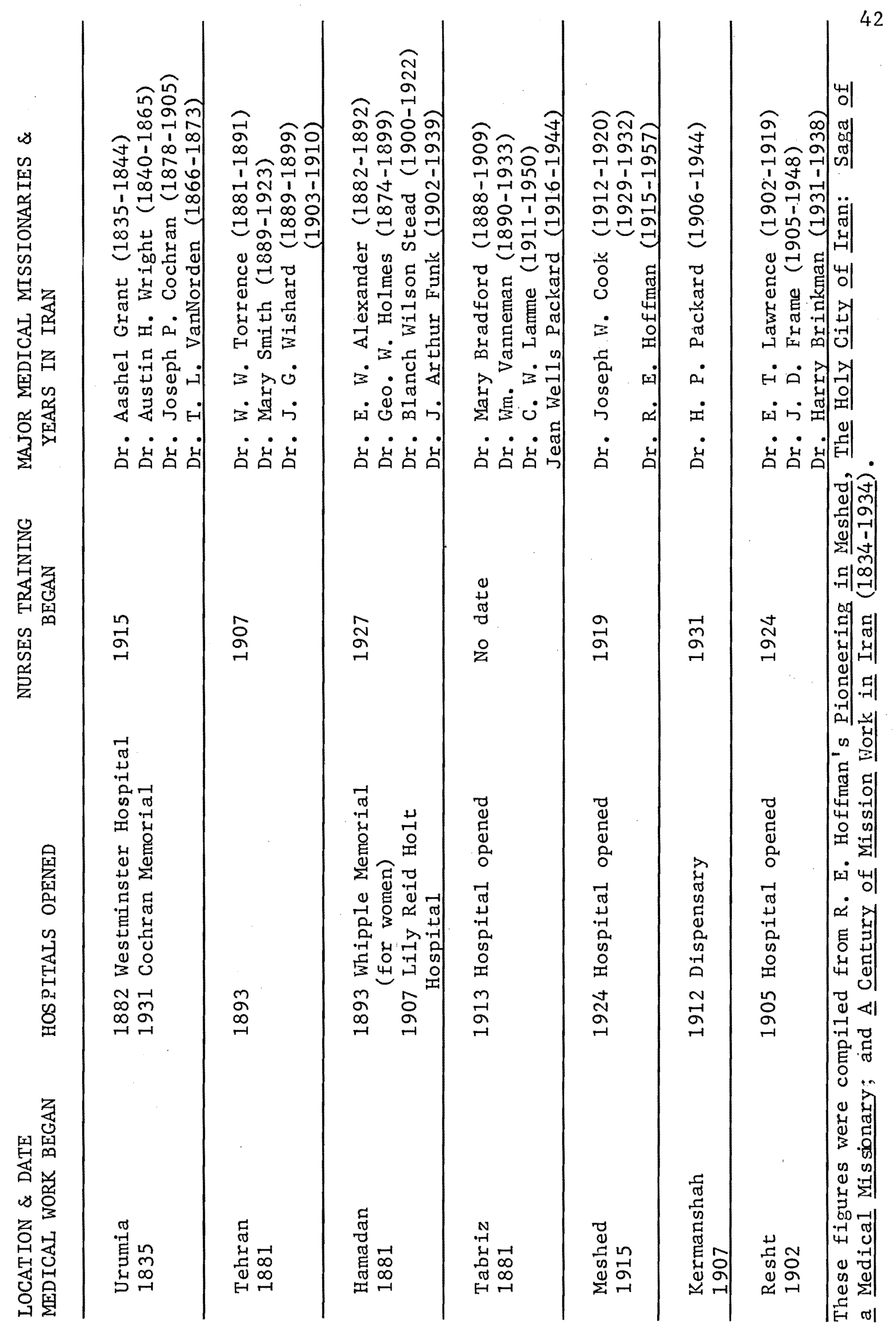


BEGINNING OF MISSIONARY PROBLEMS

Many of the early missionaries to Iran were dedicated and committed individuals, as we have already seen. However, in spite of their good intentions their presence created problems. We will deal specifically with the effect of missionary presence on the existing rivalry between the Nestorians and the Kurdish tribes and on the relationship between the missionaries and the Nestorian church hierarchy. Undoubtedly many of the problems created were unintentional or unwitting. At times their missionary zeal seems to have blinded them to the consequences of their actions. This can be blamed in part on a lack of understanding of the people and the country. Since they arrived in the country without adequate preparation, the existing relationships between the various elements of Persian society were not immediately understood. Reviewing the literature available on Iran in 1834, written almost entirely by former missionaries, world travellers or those associated with government missions, one is not surprised that the missionaries were unaware of the situation within the country. A good example of the available literature is James Morier's The Adventures of $\mathrm{Hajii}$ Baba of Ispahan (1824). Referring to Morier, who accompanied an 1811 British Mission to Iran, Dr. Moritz Wagner states that he had "added so much to our knowledge of Persia." 35 Undoubtedly some readers did not see the satire of Morier's work and believed everything they read. Without understanding a culture, some strange

$$
35_{\text {Wagner, op. cit., p. } 141 .}
$$


conclusions can be drawn and this frequently seems to have been the case with the early writers and their readers on Persia.

Turning to the continuing rivalry between the Nestorians and the Kurds, Dr. Grant was to unknowingly antagonize the situation. Shortly after arriving in Iran, Grant sought to establish a base deep in the heart of the Kurdish mountains from which he could work among the mountain Nestorians. The building which he erected had the awesome appearance of a fortress and was situated on a high hill overlooking the valley. A more conspicuous site could not have been chosen. This immediately aroused the suspicion of the Kurds as did Grant's apparent interest in the Nestorian people.

From their arrival the missionaries had worked almost exclusively with the Nestorians. This concentrated attention encouraged the Nestorians to view themselves as superior to their Kurdish neighbors and as they became more aware of the glorious past of their church they became emboldened. However, the Kurds were fearless fighters and far surpassed the Nestorians in this respect.

After arousing the animosity of the Kurds, the Nestorians were unable to defend their claims. They sought the intercession of Grant since he was a friend of the Kurdish chief as well as the Nestorian Patriarch. Grant, however, refused to intercede and was surprised that the Nestorians could see no "inconsistency in an ambassador for Christ taking part in the passing political events." 36 In spite of the fact that Grant declined to mediate, or perhaps because of it, he was to be blamed for the subsequent Badr Khan Massacre of 1844.

${ }^{36}$ John Joseph, The Nestorians and Their Muslim Neighbors: A Study of Western Influence on Their Relations (Princeton: Princeton University Press, 1961), p. 65 . 
The interest which Grant had shown towards the Nestorians was actually twofold. True he wanted to make available his medical services, but he was also convinced that these people were descendants of one of the Lost Tribes of Israel, although this belief was not shared by his colleagues. He had sought to penetrate the mountain area to find the homeland of these people. As a matter of fact he actually gathered the materials to publish a book proving this theory. Though such were his intentions, they were misunderstood.

In addition to the hostility of the Kurds, the situation was further complicated by the fact that the Ottoman officials suspected Grant of stirring up a separatist movement among the Nestorians. Therefore, when the Kurds attacked the Nestorians in 1844, it was with the full backing of the Ottoman government. Hundreds of Nestorians were killed in the massacre and the blame was placed on Dr. Grant as he had refused to intervene. The missionaries later would be blamed in other instances for just such intervention. As a matter of fact the Nestorian Patriarch's later animosity towards the missionaries was partially due to the Badr Khan Massacre. He felt that the missionaries, in spite of their verbal support of the Nestorians, had not acted in their behalf when needed.

It was incidents such as these which were to occur throughout the missionaries' stay in Iran. It is no wonder that the Home Board was continually reiterating the necessity of remaining aloof from political problems and concentrating on their original mission of evangelizing.

However, in turning to their initial intent of revitalizing the native Christianity, the missionaries also encountered problems. Con- 
tinued contact with the Nestorians and discussions of religious issues soon led them to conclude that the Christianity professed by the Nestorians was so alien to any acceptable form of Western Christianity that it would be ineffective as an instrument of conversion.

While holding fast to Christianity, in spite of severe persecution from their Moslem neighbors, they were almost as depraved and ignorant as the non-Christians about them... Hence the religion of the Nestorians was one of fasts and prayers and empty forms. 37

Yet it had been the purpose of the mission not to form a separate church, but to revive the old Church, so for some time converts were allowed to remain in the Nestorian Church and the Nestorian clergy continued to perform their religious functions as before. It was, however, becoming increasingly clear to the Nestorian Patriarch that he was in danger of losing both his position and his influence. The respect which people had once shown him was now directed towards the missionaries. It was evident that people were being drawn away from the old Church and towards a modernized form of Christianity. Without the Church, the patriarch had no assigned role in society. As he saw his prestige and influence waning he struck out at that which he considered the cause - the missionaries.

Though only two examples have been cited, it is clear that by their very presence in the country, the missionaries further antagonized certain situations within Iran. The nation had been isolated from outside forces for centuries and had survived by establishing delicate balances. The participants knew their roles and sought to maintain the status quo. Unwittingly, in their attempts to correct.

${ }^{37}$ A Century of Mission Work in Iran (Persia) 1834-1934 (Beirut: American Press, n.d.), p. 17. 
what they saw as injustices the missionaries upset this balance. Opposition to their efforts was to continue throughout their stay in Iran. Such reaction would come from various elements of society and for differing reasons. 


\section{DIVISION OF THE MIDDLE EAST MISSIONARY FIELD}

Before dealing further with opposition to missionary work, it is important to note the beginning of work among the Muslims of the area which accompanied the 1870 division of the Middle East mission field between the Presbyterians and Congregationalists. This split was not the result of any problems encountered in the field, but resulted from activities occurring in the United States. According to the sources consulted, ${ }^{38}$ this division was completely amiable.

Tracing the origin of this division one must go back to the year 1801 in which the P1an for Union was adopted to facilitate cooperation in dealing with the Western Frontier. It was agreed that a united interdenominational action would be beneficial to all concerned. The Congregationalists formed the dominant element with the Presbyterians ranking second in number. However, this union was not destined to endure. The Congregationalists tended to draw apart at an early date as they became more aware of their distinctive characteristics. In 1852 a nationa1 council representative of Congregationalists met in Albany, New York and by a unanimous vote withdrew from the P1an of Union.

The dissatisfaction was not, however, one-sided. From its origin not al1 Presbyterians were satisfied with the Plan of Union. The final 38

Rufus Anderson, History of the Missions of the American Board of Commissioners for Foreign Missions to the Oriental Churches (Boston, 1892); DeNovo., op. cit.; Kenneth S. Latourette, Christianity in a Revolutionary Age, III (New York, 1961); P. G. Mode, Sourcebook and Bibliographica1 Guide for American Church History (Boston, 1964). 
split within the Presbyterian group occurred in 1837. The critics, represented by the 01d School Presbyterians, felt that membership in the Plan compromised Presbyterian doctrines and practices. There was strong conviction that the Congregationalists were wielding too much influence over the Presbyterian congregations. However, there were also those congregations which supported participation in the Plan of Union and they became known as the New School Presbyterians. It was this group that played an active role in the formation of the American Board of Commissioners for Foreign Missions (1812), comprised of Presbyterians and Congregationalists. These two divided Presbyterian factions eventually reunited in 1869 and in the following year it was agreed that the mission fields would be divided between the newly united Presbyterian Board for Foreign Missions and the Congregationalists' American Board of Commissioners for Foreign Missions. The Presbyterians assumed responsibility for Persia and Syria and the American Board continued in Asia Minor, Armenia and Constantinople.

The Presbyterians changed the official name from "Mission to the Nestorians" to "Mission to the Persians". This name change was indicative of the broader range of their mission work after this date. It was felt that the time had arrived for a direct approach to the Muslims of the nation. Inevitably this increased work among the Muslims led to conflicts with some elements of Persian society, most notably the ulama. It is these clashes, as well as those involving the Nestorian hierarchy, that will be dealt with now. 
OPPOSITION TO MISSIONARY WORK

The opposition encountered by the missionaries came from three major elements of Persian society: the Nestorian hierarchy, the ulama and the government. Though they resisted for differing reasons, the prime consideration was maintenance of the status quo. Each of these three felt its position threatened by various aspects of missionary work.

\section{Nestorian Hierarchy}

First to be considered will be the hierarchy of the native Christian Church. According to Samuel Graham Wilson, missionary to Iran,

Priestly tricks are as easy as child's play amongst a people so inclined to the marvelous, and so governed by superstition; and it is in the interest of the monks to impede the introduction of books, and the dissemination of learning. 39

The opposition, in its early stages, was confined mainly to the Nestorian hierarchy as there was no direct interaction with the Muslims except in the area of medicine.

The Nestorian leaders had been isolated in their mountain seclusion for hundreds of years. With no formal education they had lapsed into a very static existence. This is confirmed by former missionary Edwin Wright who lived as a neighbor to Mar Shimun for two years (192123) and found him "woefully ignorant of the outside world". Also, as

$$
39 \text { Wilson, op. cit., p. } 37 .
$$


their positions were hereditary, they had long felt secure and showed no interest in change. However, the appearance of the missionaries was to pose a threat for which they were unprepared.

The education which the missionaries introduced was seen as a possible means of obtaining status within the community. Respect was shown the educated man. Greater emphasis was being placed on merit. The Patriarch feared that his position might be challenged by some of the newly educated members of his Church. It is clear that he had a vested interest in maintaining the status quo and would necessarily oppose any attempt to initiate reforms by which status could be acquired through education.

Continued exposure to the Christianity of the missionaries led some of the local Christians to begin questioning their own Church. The blind trust which had been placed in all decisions by the Patriarch was also being called into question. The new Christianity recognized no absolute ruler. This was a trait of Catholicism which the Protestants condemned.

In addition to disputing the leadership role of the Patriarch, many of the Nestorians were also turning to the missionaries to settle their disputes. Disagreements among the local Christians had previous1y been handled by Mar Shimun as he was regarded by the central government as the representative of all Nestorians. However, matters of arbitration were being increasingly referred to the missionaries. The Nestorian people realized the influence of the American missionaries and began to turn to them for mediation, particularly with the central government. Again the Patriarch saw his influence waning. 
The break from the Nestorian Church in 1871 confirmed the fears of the Patriarch. This had been a gradual process, occurring over a fifteen year period. We have already mentioned that the missionaries had decided to work within the old Church rather than form another. So although a Protestant congregation had been formed among the Nestorians in 1856, it remained within the Nestorian Church mainly because of the strong opposition of the Patriarch. Writing in 1871, the year the new Assyrian Evangelical Church declared itself independent from the Nestorian Church, a missionary referred to the old Church as

...a fossil which can never be reformed. Hence, for our Christians to live at all, they have been compelled to leave it. In part, they have been driven out; in part they have left it; and now the separation is complete. 40

Mar Shimun's earlier attempts to prevent such a separation had proven futile. He had ordered his followers to break up the mission schools and prevent preaching in the church. He also threatened those associating with the missionaries with excommunication. He had actually excommunited Bishop Mar Yohannan because of his contact with the missionaries.

In addition to these threats, the Patriarch frequently joined with the Catholic missionaries in the area, as well as the Persian nobility, in attempts to counteract missionary influence. It was said that he even wrote a "fraternal epistle to the pope" ready for anything, if he could only crush the mission. 42

${ }^{40}$ Century of Mission Work, op. cit., p. 23.

41 It was Mar Yohannan who had given Syriac lessons to Justin Perkins upon his arrival in Iran and had remained a friend of the mission. 42

Thomas Laurie, Dr. Grant and the Mountain Nestorians (Boston: Gould and Lincoln, 1856), p. 154 . 
Despite his many attempts, Mar Shimun was unable to repress the missionary efforts. It was to be the ulama who posed the biggest obstacle to missionary work, although it would be the government that would finally curtail their activities.

\section{Government-U1ama Relations}

Before discussing the reaction of the ulama and the central government to the missionaries, it will be beneficial to review existing relationships between these two indigenous elements of Persian society. Interaction between the government and the religious leaders has played an important role in Iranian history.

The Shah, though the dominant figure, has no official claim to legitimacy. That is, based on Shi'a Islam, he is only a temporal ruler entrusted with his office until the return of the Hidden Imam. To this day, this is included in the Iranian Constitution. Because of this lack of legitimacy, the Shah looked to the religious class, the ulama, for confirmation of his authority. However, the Shah also had to be wary of conspiracy and was ever cautious of allowing too much power or influence to accrue to any one individual or group, particularly the ulama. Maintenance of the status quo was a very important factor in preserving the monarchy.

The ulama were also in a rather precarious position. As the last Imam left no successors there was no established hierarchy in Shi'a Islam. However, the ulama had over the centuries acquired de facto recognition as an intermediary between the people and the Prophet. They provided direction to the community which had previously been supplied by the Imams. Based on this role, the ulama had a great deal 
of influence among the Iranian people. It was this influence which posed a continual threat to the power of the Shah.

Another significant aspect influencing the relations between the government and the ulama was judicial administration. Throughout the nineteenth century administration of religious law by the ulama had to compete with the judicial administration of the state. This duality was not amended until the introduction of the first Civil Code in 1911. Courts presided over by the ulama were known as shar' courts; the system of law controlled by the state was called 'urf. There was no precise delineation between the jurisdictions of 'urf and shar'. However, the former dealt primarily with offenses directed against the state or public security, such as "rebellion, embezzlement, forgery of coins and theft"; ${ }^{43}$ the shar' courts were concerned more with disputes and litigations of a personal or commercial nature.

The jurisdiction of shar' and 'urf courts frequently overlapped and this occasionally led to conflict. Shar' courts were powerless, however, in that they lacked the actual ability to enforce their decisions. The execution of verdicts was in the hands of the village headman, who was usually willing to nullify a decision for a price. However, the shar' courts could also serve as appeal courts in which a decision of the 'urf could be overturned.

Thoughout the 19 th century the state's attempts to assert its judicial power involved a lessening of the prerogatives of the ulama. There was a continuing attempt to expand the jurisdiction of 'urf at

43 Hamid Algar, Religion and State in Iran 1785-1906, The Role of the Ulama in the Qajar Period (Berkeley: University of California Press, 1969), p. 13 . 
the expense of shar' and to submit the latter to some kind of state contro1.

The missionaries usually fared better in civil courts than in those controlled by the ulama, so it was to their advantage to have the ulama's judicial power checked by the central government. One such instance of curtailment of power occurred in 1881 when, as a result of negotiations between the British Minister and the Persian Minister of Foreign Affairs, authorities were instructed that suits between Muslims and Christians would be tried, not by religious, but by civil courts and Christians would be placed on equal footing with Muslims in giving evidence.

\section{The Ulama}

The ulama presented the greatest opposition to missionary work and was the most effective because of their influence among the people. Their reaction cannot, however, be considered merely a self seeking one. That is, although they had a great deal to gain by maintaining the status quo, they also felt that it was their responsibility, as religious leaders, to oppose the introduction of Christian or Western ideas and values. Consideration must be given to both of these motivations.

We have already mentioned the role of the ulama in education. Certainly they opposed infringement on their role as educators. However, they also realized that there was more than technical skills to be acquired through missionary education. New ideas and values were being instilled; both originated from Christian nations. Such ideas

$$
{ }^{44} \mathrm{Joseph} \text {, op. cit., p. } 90 .
$$


could be instrumental in effecting change within society; change which the ulama saw as a threat to the Iranian people and their way of 1 ife. The ulama also felt the Muslim religion was being undermined by the missionaries. Although we have noted that they were unsuccessful in this area, their success in other areas called the existing system into question. The medical work of the missionaries had shown that modern technology and skill could cure illness in instances in which prayers and Quranic readings had proven ineffectual. It was no 1onger fated that man should die from disease which could now be prevented through the use of vaccines and innoculations. Man had gained some control over his destiny and in so doing had lessened the former reliance on religion.

The judicial influence which had afforded the ulama a great deal of power in the past was also being usurped. Matters were being taken from their control and placed under the jurisdiction of specially appointed protectors of the Christian minorities. We have also noted the 1881 decision which gave Christians equal rights in seeking justice and placed them under the control of 'urf courts. In such instances the government was able to effectively limit the power of the ulama, while complying with the requests of the minorities.

It cannot be concluded, however, that the entire membership of the ulama opposed western innovations. Those who had the greatest exposure to the West were naturally more receptive. They wished to take what the West could offer and accommodate it to the needs of their country. There are scattered accounts of missionaries being allowed to preach in a mosque and being assisted in disseminating medical 1iterature by religious leaders. Though these were undoubtedly exceptional 
cases, they do confirm the acceptance of Western concepts by some members of the religious class.

The Government

Overall government relations with the missionaries were cordial. The central government seemed eager to take advantage of the many benefits which the missionaries could offer. Certain concessions were made to facilitate the missionary work. For example, the Shah ruled that no duties would be charged on the importation of medical supplies. The Shah also occasionally assisted the missionaries in their disputes with local officials. According to James A. Field,

...difficulties with a local magnate were followed by royal intervention on the side of the missionaries and the unsolicited issuance of a firman endorsing and encouraging their labors. 45

Although it might appear that the missionaries were usually awarded favorable judgments, this was not the case. Often because of the distance involved between the capitol and the outlying provinces, the edicts were not enforced. The Shah depended on local officials to keep him informed and these individuals were sometimes opposed to the missionary presence. Frequently money would be paid to keep certain matters from reaching the attention of the Shah.

The Shah evidently did not feel the American missionaries posed a threat to his contro 1 . While the British and Russian governments wielded a great deal of power, the United States did not have such commanding influence. Even after establishment of diplomatic relations with Iran, the American government played no significant role in the

45 James A. Field, America and the Mediterranean World 1776-1882 (Princeton: Princeton University Press, 1969), p. 185. 
affairs of Iran. The American missionaries were thus viewed as neutrals who had no vested interest in the internal situation of Iran.

The 19 th century rulers of Iran had a keen interest in attaining the attributes of western civilization. We have already noted the establishment of the Dar al-Funun as evidence of this. Additionally, students were intermittently sent abroad at government expense. 46 Nasir ed Din Shah himself travelled to Europe in 1873, 1878 and 1889. His son, Crown Prince Muzzaferradin, had European tutors for his sons and could himself read and write French. Many European doctors were brought in as court physicians. All of this illustrates the government's interest in acquiring western technology and skills.

However, such instances do not provide the entire picture. We have already mentioned the role of the ulama in granting de facto recognition to an "illegitimate" government. In order to obtain the continuing support of the ulama the Shah occasionally found it necessary to acquiesce to their demands. It is likely that restrictive measures placed on missionary activities were the result of pressure from the ulama. Though the Shah was usually agreeable to the work of the missionaries, full backing of all their endeavors would arouse the hostility of the ulama who were still very important in controlling pub1ic opinion.

${ }^{46} 1811$ (2 students); 1815 (5 students); 1845 (2 students); 1858 (40 students) 


\section{ESTABLISHMENT OF DIPLOMATIC RELATIONS}

It has been noted that the United States had no official diplomatic relations with Iran until 1883. Prior to this date the American missionaries in Iran had been under the protection of both the British and Russian consuls. From their arrival in 1834 until 1839 they were under British protection; 1839-1851 under Russian protection; and 1851 until establishment of diplomatic relations in 1883 under British protection. The available information does not account for the changes or the dates involved. Perhaps they relied on that embassy having the most influence; maybe they withdrew from protection when the foreign government was involved in a dispute with the Iranian government. Whatever the reasons, dependence on these foreign embassies proved difficult. The American missionaries attempted to remain neutral in the face of Anglo-Russian rivalry, although relying on one or the other to ensure their safety and intercede in their behalf. Additionally the fact that the Americans were tied to foreign consuls implicated them, if only by association, with the policies and actions of that particular consul.

It appears that one of the prime considerations in forming diplomatic ties with Iran was the protection of American missionaries, concentrated in the Urumia area. As the hostilities between the Nestorians and Kurds intensified, the position of the missionaries became more tenuous. A dispatch in the Tehran press in the early 1880's reported:

There is great excitement among the inhabitants of Urumia against the Christians--especially against the American 
missionaries--for their supposed complicity with the Kurds. ${ }^{47}$

Certain individuals, engaged in lobbying for establishment of diplomatic relations, had a personal interest. Ohio representative, R. R. Dawes, brother-in-law to missionary William Shedd, asked the State Department in November of 1880 to appeal to the Persian Government to protect the lives of fourteen American missionaries in the Urumia area. $^{48}$ Another individual advocating diplomatic relations was Representative Andrew G. Curtin from Pennsylvania. He had been the U. S. Minister to Russia and was well aware of the situation in Iran. There was strong sentiment that the services being rendered and the large number of Americans involved, demanded the active protection of the U. S. government.

Negotiations had been secretly underway since the early $1850^{\prime}$ s for diplomatic relations between the two countries. The strong role of the British in Persia at this time necessitated private discussions. However, because of problems encountered in reaching an agreeable settlement, it was not until 1883 that a treaty was ratified. The position of U. S. Minister to Iran was first offered to Rev. Henry Jessup, a former missionary to Turkey. However, on his refusal it was given to S. G. W. Benjamin, himself the son of a former missionary to Turkey. It is interesting that the son of a missionary was offered this post. It might be that the government felt that someone familiar with miss-

${ }^{47}$ Wilson, op. cit., p. 122.

${ }^{48}$ Abraham Yeselson, United States-Persian Diplomatic Relations 1883-1921 (Rutgers University Press, 1956), p. 23. Rev. William Shedd was also brother-in-law to the Hon. Curtis D. Wilbur, Secretary of the Navy in Coolidge's cabinet (1924-29) and cousin to Vice President Charles Dawes (1925-29). 
ionary work would be well suited for the position, particularly as protection of the missionaries was a major function of the post. It was just such appointments which later brought the motivation of missionary work into question. However, living abroad, either as missionaries or as children of missionaries, these individuals acquired a knowledge of the country unattainable from the outside. According to U. S. Minister Benjamin, the training period provided for foreign ministers or ambassadors was very limited. He suggested that a more intensive training program be initiated prior to sending U. S. emissaries abroad. He also felt that the two year term of office was too brief for adjustment to a new culture. It was to be some time before concrete actions were taken in this direction.

Benjamin, though himself from a missionary family, was critical of some aspects of missionary work. He had very strong feelings against proselytizing among the Muslim inhabitants. According to him if missionaries attempted to convert Muslims they should be asked to leave the country and "I should be very slow to condemn the Shah if he should follow such a course in such case." 49 Benjamin's impression of the Persian people during his two year stay in Iran was very favorable. He felt that great progress could be made within the country if foreign nations would refrain from interference. Certainly the American government followed his advice in their early relations with Iran.

Even after establishing diplomatic relations with Iran, the United States had no intention of taking an active part in political

${ }^{49}$ S. G. W. Benjamin, Persia and the Persians (London: John Murray, 1887), p. 362 . 
involvement. Given the vicious power struggle between the British and Russians within Iran, the geographical remoteness of Persia from the United States, America's traditional isolationism, and absence of direct trade between the two countries, it is not surprising that America was extremely wary of involvements in Persia. Those lobbying for diplomatic relations were fortunate in securing them and could hope for no commitment beyond the protection of American missionaries stationed there.

Yet if the U. S. government was unwilling to intervene in events within Iran, certain missionaries in the field were. Because of their commitment to the people and their interest in improving conditions within the country, they became increasingly involved in activities unrelated to their religious roles. 
MISSIONARY POLITICAL INVOLVEMENT

American missionary involvement in actions of a political nature originated in their role as arbitrators. Several references have been made to their mediation on behalf of local Christians. The major reason for their intercession was that cases involving Muslims and Christians were originally tried in a shar' court, favoring the Muslim since Christian testimony was unacceptable in such courts. ${ }^{50}$ In order to secure a fair decision, the missionaries often interceded, asking the central government to review the case.

The mediation role and the resultant increasing influence of American missionaries caused concern among the British and Russian consuls. They opposed any interference with their control of the country. At their insistence, a special governor (sarparast) was appointed to the Christians in the hope that he would "protect them from Mus1im acts of discrimination." 51 No doubt this post was actually created because the Russians and British wished to limited the growing influence of the Americans with the central government.

Within a few years, however, the 1itigation had increased tremendously. As the office of sarparast was compensated in part by fines extracted, people were actually encouraged to make complaints. Not only

${ }^{50} \mathrm{~A} 1$ aw passed in 1881 gave equal footing to Muslims and Christians in court testimony.

51 Rufus Anderson, History of the Missions of the American Board of Commissioners for Foreign Missions to the Oriental Churches, I (Boston, 1892), p. 325 . 
were problems involving Muslims and Christians being referred to him, but even in disputes among Christians, appeals were made directly to the sarparast. Because of the numerous problems created, this office was eventually abolished through the efforts of the missionaries and local officials. ${ }^{52}$

In 1881 the government intervened and placed a11 legal matters between Christians and Muslims under the jurisdiction of the civil courts. The Americans helped establish a general committee made up of representatives from the Nestorian, Catholic and Protestant community to help in settling interdenominational disputes. Those matters involving disputes among Christians were again referred to the religious leaders. The missionaries seemed satisfied with these arrangements and thereafter intervened on1y occasiona11y.

Mediation was, however, only the beginning of political involvement by the missionaries. Other instances can be cited in which they took an active role in political movements. Even in these instances, however, the missionaries were motivated by their concern for the we1fare of the Persian people.

Undoubtedly the best known political action was that taken by twenty one year old Princeton graduate, Howard Baskerville. He had originally come to Iran in 1906 to teach English in the Urumia school. He later became involved with the Constitutional forces who sought to restore the constitution granted in 1906 and to wrest the country from Russian control.

Baskerville's resignation from missionary service in 1909 was prompted by pressure from his superiors who forbid him to take an ${ }^{52} \mathrm{Joseph}$, op. cit., p. 84 . 
active part in the Constitutional Movement while still associated with the mission. $^{53}$ Had Baskerville not been killed in April 1909 during an attempt to capture an artillery site, it is certain that he would have been censored by the Home Board in New York.

Though he is the only missionary known to have taken an active part in the Constitutional Movement, that is not to say that other missionaries were not sympathetic. One missionary is known to have let his servant take part in military drills and still continue to draw his regular pay from the mission. However, the missionaries had received orders from their Home Board that they were not to take an active part in politics for fear of losing their right to stay in the country. Therefore, they provided only moral support to the Movement. 54 A review of missionary political activities would not be complete without the inclusion of the Rev. William Shedd's role in northwestern Iran during WWI. This area was the site of continual fighting and occupation by Turkish, British, Russian, Persian and Kurdish troops. As a result of famine and disease arising from the continual warfare, the missionaries found themselves ministering to the relief needs of the community. Thousands fled to the mission compound seeking food and shelter. Both were provided in spite of directives from the U. S. State Department forbidding such activities which might be construed as aiding

${ }^{53}$ An interesting sidelight is provided by former missionary Edwin Wright (letter to author dated Jan. 28, 1973), whose father was a missionary in Iran during this period. Mr. Wright indicates that Baskerville's move was an impetuous one saying he was "young, emotional and idealistic." After being urged to wait before marrying Agnes Wilson, the 17 year old daughter of $\mathrm{Dr}$. S. G. Wilson, Baskerville suddenly went off to join the Constitutional army and was killed.

54 Letters of Dr. T. Cuyler Young (2/7/73); Dr. Yahya Armajani $(2 / 17 / 73)$; Rev. Wm. Wysham $(1 / 23 / 73)$; Rev. John E1der $(1 / 24 / 73)$. 
the enemy.

The area was in a deplorable state and had become increasingly reliant on Russian protection from the incursions of the Turks and Kurds. When Russia withdrew from the war in 1917, their troops, on which the Urumia inhabitants had relied, were also withdrawn. This left the Christians of northwestern Iran prey to the raiding Turkish and Kurdish forces. Free-lance Russian officers, with the assistance of Mar Shimun and Agha Petros, an Assyrian mountaineer, helped organize an army of Christians to protect the area after Russian withdrawa1. 55 American support for this effort came in the form of money "borrowed" from the Near East Relief Fund by the Rev. William Shedd. Early in $1918 \mathrm{Dr}$. Shedd had reluctantly accepted a State Department appointment as honorary vice-consul. The dual roles of missionary and government official made action by Shedd extremely difficult. As a missionary he was interested in the welfare of the people, but as a government official he had been ordered to refrain from any involvement. Although he had no official right to supply arms or financial support to the Christian armies, he did so with a clear conscience. Robert Daniel confirms that "indiscreet American missionaries diverted some $\$ 100,000$ in relief funds to support the Christian army $!^{56} \mathrm{He}$ further contends that Rev. Shedd seriously compromised the American government by signing, in his capacity as vice-consul, an offer to pay the bills of the Christian army. Shedd had also issued orders summoning "every young man who has a rifle to join the Christian army without any

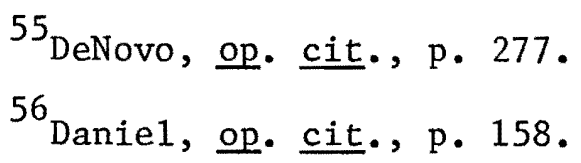


delay or excuse," $" 57$ an action which Shedd admitted was directly in contravention of orders from the State Department.

However, neither the British nor Christian armies were able to prevent the Turkish occupation of Urumia in July of 1918 and those who had sought refuge in the mission compound (about 17,000) fled into central Iran for safety, led by Rev. Shedd. He, along with thousands of others, died before reaching their destination.

The above cited instances serve to illustrate the political implications of missionary action. Such instances were to give credence at a later date to the contention that missionaries had overstepped the bounds of their commitment and assumed a secular (politica1) role. Such actions increased suspicion of the missionary work. With the arrival of Reza Shah Pahlavi, successor to the Qajar dynasty, measures were taken to restrict missionary efforts.

57

Mary Lewis Shedd, The Measure of a Man: The Life of William Ambrose Shedd, Missionary to Persia (New York: George H. Doran, 1922), p. 243. 
Change of Dynasty - Qajar to Pahlavi

The Qajar dynasty, which ruled Iran from 1795 until 1921, was one increasingly dominated by foreign powers. Throughout the period the prevailing forces were Great Britain and Russia. As a result of the numberous concessions granted, ${ }^{58}$ Iran was forced to seek loans from both powers. As debts accrued, reliance on outside assistance also increased. Associated with this was a decrease in the Shah's authority. Even after the granting of the constitution in 1906 the situation was not greatly altered. Foreign powers still heavily influenced events in Iran and the Shah was able to maintain his position only through appeasement of these powers. These were the conditions which led to the overthrow of the Qajar dynasty and the accession of Reza Shah Pahlavi:

Upon assuming power in February of 1921, Reza Shah quickly assessed the condition of the country and initiated actions to once again concentrate power in the monarchy. Following a four year interim period he had himself officially crowned and lost no time in initiating measures to achieve centralization and release the country from foreign contro1.

${ }^{58} 1854$ telegraph concession granted to British; 1878 Russians organized and staffed the Cossack Brigade; 1889 British opened the Karun River to commerce; 1890 Imperial Bank of Persia concession granted to the British; 1891 British given tobacco concession; 1890's Russian concession for bank and railroads granted; 1901 British granted oil concessions. 
$\underline{\text { Similar Measures of Abdul Hamid }}$

It will be helpful before assessing the actions of Reza Shah, to review measures taken by Abdul Hamid in his efforts to centralize power and limit foreign influence in the Ottoman Empire. There are similarities between the actions of these two leaders.

Many of the reforms in the Ottoman Empire were directed toward education because of the foreign influence in this area. In an attempt to limit this foreign contro1, Abdul Hamid Forbid, or at least delayed, the transfer of property or the granting of a building permit for new schools. He also utilized newly adopted school laws whic h established standards for teaching certification, the curriculum, and the physical facilities of the school. These laws were not inherently objectionable and were part of a legitimate effort to strengthen the state school system. In some cases Ottoman dissatisfaction with foreign schools was triggered by the French schools and the Americans were caught in the backlash. In other cases riva1 Roman Catholic and Greek Orthodox clergy encouraged Muslim authorities to object to the American schools. Yet other attempts were aimed directly at the American schools because of the revolutionary activities of the Armenians with whom they had been identified.

Resolution of these problems proved difficult. The Americans frequently complicated matters by assuming the position that they were free to operate schools as soon as their teachers, textbooks and curriculum met Ottoman standards. They did not wait for the issuance of an official permit attesting to that fact.

Another source of contention was the fact that American schools represented a foreign cultural influence that not only taught from 
foreign textbooks but from foreign viewpoints. An early step towards strengthening national control over all schools functioning within their jurisdiction was the banning of compulsory Christian instruction for Muslim students attending mission schools.

As a national school system gradually emerged in Turkey foreign schools, both elementary and secondary, were permitted to function as Iong as they observed the standards prescribed by the state. The most important of these regulations required that beginning in 1932 the teaching of history, geography and civics be carried on by Turks, in Turkish and from Turkish textbooks. A policy was also announced (1928) that equal pay was required for American and Turkish teachers irrespective of differences in training.

Such actions, while strengthening the government's position, a1so served to limit the influence of the foreign schools. This was not merely a coincidence. There was always the threat of revolution encouraged by foreign powers and all means were taken to prevent this. Similar measures were undertaken by Reza Shah in his attempt to centralize power and eliminate foreign control.

Restrictions on Education in Iran

If we consider those measures which directly affected the educational missionaries in Iran, four stand out markedly. The first of these came shortly after Reza Shah's coronation. In 1928 the Ministry of Education began taking steps to obtain conformity of all educational institutions within Iran. In order to ensure this, regulations were established for a standardized curriculum. According to Issa Khan Sadiq, former Minister of Education, this enactment stated that all courses of 
study in the first four years of elementary school must be taught in the Persian language; ${ }^{59}$ beginning in the fifth grade courses in Persian, Arabic, mathematics, and the geography and history of Persia were to be mandatory and taught according to official curriculum structure from specified texts; and the Bible must not be taught to Muslim students. 60 These restrictions were to alter the structure of missionary education. as there had previously been freedom in selection of texts and establishment of guidelines and emphasis. However, with the exception of eliminating Bible readings, the missionaries adjusted their curriculum and continued their work.

The second measure, enacted in 1932, was extremely damaging to missionary education. Under this decree the government ordered that a11 children in elementary classes (grades 1-6) must attend government owned and operated schools. This dealt a heavy blow to missionary education as it eliminated approximately $75 \%$ of their enrollments. ${ }^{61}$ Not only were enrollments drastically decreased, but the missionaries contended that this greatly reduced the caliber of those students entering the seventh grade of their schools. They felt that students who had availed themselves of missionary education were better prepared than their Persian educated counterparts. This is difficult to document, however, as prior to 1929 mission school students were not required to compete in the end of year examinations given to govern-

${ }^{59}$ Up until this point the missionaries had taught in the language of the Christian minorities. This language requirement by the government was intended to decrease minority ties.

$60_{\text {This was circumvented with approval of teaching selected works }}$ of the prophets and philosophers within the Ethics course.

61 A Century of Missionary Work, op. cit., p. 100. 
ment students. Yet it cannot be disputed that the missionary education provided was exceptionally good. To quote a former Tabriz mission school student whose parents and grandparents had also been mission educated:

Our schools were multilingual. English was started at the third grade. From the 7 th grade all subjects were taught in English except languages which were French or Russian (optional), Armenian for Christian students only and Persian. School started at 8:00 and ended at 4:00. There were no optional courses except languages, consequently students who lasted and graduated were very well educated. Courses taught were as follows:

$\begin{array}{lll}\text { algebra } & \text { Bible } & \text { agriculture } \\ \text { geometry } & \text { ethics } & \text { French } \\ \text { solid geometry } & \text { sociology } & \text { Persian } \\ \text { cote geometry } & \text { astronomy } & \text { Armenian } \\ \text { accounting } & \text { botony } & \\ \text { physics } & & \end{array}$

A diploma from Tabriz Memorial School was given the same value as two years of college by the New York Board of Regents. My brother, after finishing high school and with only five months of college in Iran came to the U. S. in 1943 and was accepted into the third year of Worcester Polytechnic Institute and later on completed a masters degree from M. I. T. and Carnegie Institute. So you see

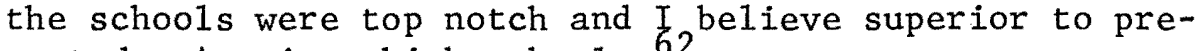
sent day American high schools. 62

Actual missionary school closures did not begin until 1933, this being the third significant government measure to curtail missionary education. 1933 marked the end of the Urumia mission under the pretext that it was located in a military zone and was being closed for the protection of the missionaries. At this point political activities begin to play a prominent role in deciding the fate of the mission schools.

It has been noted throughout this paper that the missionaries worked closely with the minorities of Iran. Along with this close 
association special bonds developed between the two. The missionaries looked upon these individuals as unique and indeed they were. Yet in making these people aware of their distinct past, the missionaries were also alienating them from Persian society. The missionaries had instilled a deep sense of pride in their cultural heritage. These actions cultivated a sense of individuality among the minorities. They had long remained a distinct entity, never fully integrated into Persian society.

As mentioned earlier, one of the major goals of the newly established Pahlavi dynasty was unification of the nation. This could be obtained only at the expense of diminishing or eliminating more 1ocalized ties. This decision threatened the cultural uniqueness of the Christian minorities. The conflicting goals of the government and the minorities were to result in the curtailment of the prerogatives of one. In this case there was no doubt that Reza Shah would prevail. Perhaps it was the 1920 Gilan Revolt which awakened Reza Shah to the increasing desire of the minorities for separate identity. Being aware of the threat posed by such national movements, he took measures to eliminate local loyalties and in their stead to create a sense of identity to encompass the entire Iranian nation. His closure of the Urumia station in 1933 was one of the early measures taken to accomplish this goal. Government schools would replace those of the missionaries and would attempt to create a sense of national pride.

Reza Shah was aware that foreign domination had been a major cause of the increasing weakness of the Qajar dynasty and naturally sought to abolish such outside control. One can view this as yet 
another consideration in closure of the mission school in Urumia. Certainly throughout the Qajar dynasty the northwest area of Iran played a very crucial role. The city of Tabriz, provincial capital of Azerbaijan, had been a center of important political activity, particularly as it was the seat of the governorship of the Crown Prince. Because of its importance, foreign influence in this region was suspect. An additional factor for protection of this area was its proximity to Russia. It was an acknowledged fact that the Russians had been instrumental in affecting the 1920 revolts in the provinces of Gilan and Azerbaijan. Certainly the desire to limit foreign interference in internal affairs was sufficient reason to close the Urumia station. The Urumia school was the first to be closed but others were to follow. In 1939 the government initiated the final measure which called for termination of all foreign schools in Iran. This order had been given only two weeks prior to the beginning of the 1939-40 school year and initially stated that no foreign schools would be allowed to operate that year. However, the missionaries petitioned the government through their Home Board and it was agreed that they would complete the academic year and that all transferences of schools would be effective in 1940 .

$\$ 1,200,000$ compensation was paid to the Board and though some contended that the sum paid was not commensurate with the market value of the property at the time, most would agree that it was a fair settlement on the basis of original investment. DeNovo notes that in 1939 capital invested in missionary property was estimated at $\$ 2,577,000$ about two-thirds of which was in Tehran. This figure would, of course, 
include all medical facilities.

\section{Indigenous Private Schools}

Government control of the indigenous private schools followed soon after restrictions were placed on the mission schools. Their curriculum, textbooks and examinations were made to conform with those of the state schools, and teachers were subject to approval by the Ministry of Education. Finally in October of 1930 official state recognition was given to those private schools that "qualified under the academic and moral standards of the Ministry." 64 In this manner all nonconformist private schools were legislated out of existence, since their certificates and diplomas had no value for employment purposes. An example of this coercive government policy was the closing of the Baha' $i$ schools in October of 1934, because they observed a religious holiday not recognized by the state. The Armenian schools were also closed in 1939 in an effort to assimilate the minorities.

Restrictions on the Ulama

During the Qajar period the ulama had played an important role in government activities. They had acquired a great deal of influence and were a factor to be considered by any king wishing to maintain his authority. Under the rule of Reza Shah the ulama, too, felt the tightening controls.

63 DeNovo., op. cit., p. 315. It is interesting to note that at this point, the missionary investment was far more significant in volume than American commercial investments. For example, four New York City rug firms had about $\$ 50,000$ invested in Iran, and the Singer Sewing Machine Company had perhaps $\$ 60,000$ in its fifteen agencies.

$$
{ }^{64} \text { Banani, op. cit., p. } 96 .
$$


At one time Reza Shah had been inclined to follow Turkey in the declaration of a secular state, but opposition in Iran, particularly among the ulama, had proven stronger than he anticipated and he was obliged to withdraw. Reza Shah realized the power of the ulama and the obstacle they presented to reform and centralization. Measures to lessen their authority were imperative; however, such measures must not arouse public anger. While undermining religious influence, the religious clause remained in the constitution, laws were framed in such a manner that they did not infringe openly upon the Islamic Code and anti-Islamic propaganda was forbidden.

Yet measures were taken to weaken the power of the ulama. One of the first decisions was to nationalize all religious endowments $(\underline{\operatorname{vag} f s})$. These had been very powerful institutions and concentrated wealth and influence in the hands of the mutavalli (administrator of the endowment). Additiona11y, in 1935 controls were placed on the public performance of the ta'ziye (passion plays reenacting the martyrdom of Imam Hussein) making them public attractions for Muslims and non-Muslims alike, and thereby reducing their strictly religious character. A committee was also appointed to "discipline, reform and supervise the teaching in the makhtabs. "65

These attempts by the central government to curb the powers of the religious segment of the country affected the American missionaries. as we11. Certainly, it was impossible to limit the power of the ulama while allowing Christian missionaries free rein in the country.

65 Banani, op. cit., p. 92. 
Limitations on Medical Work

Under Reza Shah, the medical work of the missionaries was also restricted. Even prior to his ascent to the throne, the government had attempted to establish certain health measures. However, they proved ineffectual and it was to be with the advent of Reza Shah that successful steps were taken to improve public health within the country. In 1910 the government took the first action towards introducing vaccination in Iran by putting aside "10\% of the tax on transportation... for improvements in public health and particularly for general and free vaccination against smallpox and diptheria." 66 Unfortunately many people still rejected vaccines, however, saying that it was up to God to decide man's fate and man should not interfere. They were not alone in objecting to the vaccinations. Upon learning that smallpox vaccine contained serums from human sources, the clergy waged an effective campaign against vaccination and rendered the government's efforts useless. As a matter of fact, the religious leaders in Iran provided one of the major obstacles to public health reforms. A 1925 report of the League of Nations reports:

The beliefs of the people and the teachings of the religious instructors or mullas, as they are called, have not only an effect on the character of the people but also prevent the introduction of sanitary and other reforms. The opinions of the leaders of Moslem thought are important factors in all affairs of state.... Many of the customs of the people were interpretations of the Koran. The belief that all running water which is open to the air is good and safe for drinking is taught by the religion. Dissection or postmortem examination of bodies is forbidden.

In 1911 measures were taken to regulate the practice of medicine, in particular to control the numerous quacks who had no medical

${ }^{66}$ Banani, op. cit., p. 62 . 
training whatsoever. This was approved by the Maj1is. Licenses were necessary for all practitioners, requiring them to have graduated from a medical college. A certificate of knowledge from the American mission hospita1 in Tehran was accepted in lieu of a diploma.

It is important to note that none of these laws were fully implemented. Even if the government of the pre-Pahlavi period had possessed the authority to enforce these laws, the lack of physicians and of medical facilities would have been two great obstacles in their path. In 1924 there were only 905 physicians in the whole of Iran. Of this number only 253 possessed medical diplomas from accredited schools. Out of the total 905 physicians, 323 practiced in Tehran, making the ratio in that city $1: 680$ and in the rest of the country $1: 16,800$. Because of this large concentration in the capitol there were many people still not being served by medical facilities.

In spite of the lack of cooperation from the ulama, Reza Shah was able to accomplish what his predecessors had been unable to do. A Department of Health was established to vaccinate for smallpox, typhoid, and when epidemics threatened, for cholera, using vaccine made at the Pasteur Institute in Tehran; and to inspect eating places, slaughter houses, barbershops and baths for sanitation. They were also to conduct free clinics and to see that doctors, midwives, druggists and dentists had permits to practice.

Improvements were also made in medical instruction. Tehran University was enlarged, with impressive new buildings, and the medical school was modernized. Dr. Edward Blair, of the mission hospital in Tehran, was employed to set up the dissection department and in 1929 gave a course in ear, nose and throat. In the mid-30's he was one of 
the doctors conducting a newly introduced course in anatomy at the Imperial University. This course involved dissection and was a radical introduction in Iran.

In 1932 a new medical practice law restricted practice of foreign doctors to those who had at least five years previous experience and could pass the newly established government examination. This proved a hardship to the medical missionaries as doctors had previously been recruited from among those completing their internships. This law further designated a particular city in which the individual could practice. Limiting the area of practice necessarily eliminated itinerating and made it difficult to transfer missionary doctors from one station to another.

In addition to licensing new doctors, a commission of three doctors was established to check qualifications for medical licenses of doctors already in practice. Mr. Pakravan, governor of Meshed, asked Dr. R. E. Hoffman, a medical missionary in Meshed, to serve on this committee. This is another example of missionaries assisting the government in medical work.

Great progress had been made in initiating programs in the area of medicine and public health in a relatively short period of time. These programs were to be interrupted by WWII and the abdication of Reza Shah in 1941.

WWII altered missionary medical plans in Iran. As German armies invaded the Caucasus, an invasion of Iran seemed possible. Foreseeing the need for providing medical services for military personnel, the United States Army offered to rent the Tehran mission hospital for two years, at $\$ 400$ per month. Since all of the hospitals were now working 
under short staff conditions and both doctors in Tehran had resigned, the mission accepted the offer and closed their work in Tehran. The hospital equipment and supplies were distributed among the other five hospitals in Tabriz, Meshed, Hamadan, Resht, and Kermanshah, bringing to a close fifty years of medical work in Tehran.

Although some restrictive measures were removed following the 1941 abdication of Reza Shah, the missionary work conducted after this date was limited. The government had taken over the areas of education and medical work and was making great progress. The missionaries had provided the services when they were not available from other sources, but now the demand was being met by the Iranian government. For a11 purposes the century of mission work in Iran was brought to a close. 
THE FINAL CHAPTER

There were many factors involved in introducing Western culture and values to Iran during the 19 th and early 20 th centuries. Students were sent abroad, foreign governments trained Iranians as translators, and there was also the presence of various foreign elements in Iran. Among those in Iran, the missionaries played an important part in bridging the gap between East and West. American missionaries had a particularly significant role as they were the most numerous and had established the earliest mission schools and hospitals. It was through these two channels that they transmitted Western knowledge. I.t was also in these two areas that they had their greatest impact on the country.

Conditions within Iran account in part for the influence which the missionaries had throughout their one hundred years in Iran. Of great importance was the mood of the country upon their arriva1. Iran had just suffered two defeats by the Russian military. It had been rudely awakened to the superiority of Western technology and was quick to realize the need for acquiring such skills. Because of this the government was receptive to the introduction of Western education. Though a limited number of students were sent abroad for studies, such knowledge was now being offered by the mission schools in Iran, Although opposed to the religion which the missionaries brought with them, the government was anxious to take advantage of the other benefits that the Americans could provide. 
The fact that educational opportunities were limited in the country also added to the effectiveness of the missionaries. Those desiring a modernized education for their children had very few options. Students could be tutored privately, sent abroad, or instructed in foreign schools in Iran. The education offered by the indigenous religious schools was extremely limited and of no value in acquiring technical skills. Yet it was just such knowledge which was being sought as a result of exposure to the West. In this area the missionaries could provide a great deal.

In addition to the education offered by the Americans, the medical knowledge of their doctors was without question far beyond that of the local practitioners. Yet in order to practice, the missionary doctors had many obstacles to overcome. They were, of course, Christians among a Muslim majority. Certain religious leaders preached against them and forbid the people to go to them for treatment. An even greater barrier was the engrained superstitious beliefs of the people. It was extremely difficult to convince them of the benefits of modern methods and medicine. Various teachings of the Quran also posed problems in providing modern medical treatment. Though the Islamic religion taught cleanliness, it was as a religious ritual, not as a means of sanitation and prevention of disease. It was difficult for the people, so accustomed to tradition, to adjust to the ideas behind modern medicine. Yet such changes were necessary before the full effects of medical missionary work could be felt. Through their continuing efforts among the people, the missionaries were able to slowly alter the outlook of many. They were viewed not only as educators and doctors, but also humanitarians. They were 
always there to offer assistance during times of famine and disease. Many gave their lives while helping the Iranian people. They were instilling a sense of compassion and responsibility towards others. By establishing orphanages and working among the lepers, they showed their concern for all people, not only those select few who shared their religious convictions. Of course they never stopped hoping that converts would be found among the thousands to whom they ministered. Yet though they were seldom successful in these endeavors they continued to work towards improving conditions within the country. Though not converting the people, they were having an increasing influence upon their lives.

of those missionaries working in Iran, the Americans were viewed in a special 1ight. They were not, like the British and Russians, tied to political intrigues within the country. That is not to say that the British and Russian missionaries were in the country only to gain additional influence, but the fact that their governments were gaining control over the economic and political life of Iran was definitely a drawback in their work. The American government, on the other hand, had made it clear that it had no interest in becoming politically involved in Iran. This absence of U. S. government presence placed the American missionaries in a favorable position. Because of this they were able to continue their work uninterrupted for over a century, while other missionaries intermittently withdrew because of political turmoil.

Undoubtedly the greatest influence the American missionaries had was on their students. Many of them remember we11 their education and educators. It is interesting, too, the number who bring up the values 
acquired while attending the mission schools. The dignity of labor, worth of the individual, importance of integrity and honesty, are a11 values cited by former students. And it was these very students who were to play significant roles in 20th century Iran. Many mission school graduates held positions of importance in government, banking, education, commerce, medicine and other fields. These men and women. are tangible examples of missionary influence in Iran - an influence which survived long after the missionaries withdrew from Iran.

In spite of the direction which the American missionaries had provided, their role was eventually brought to a conclusion partially because of their growing influence. They had sought to modernize the country and raise the standards of the people. Some improvements had been made during the 19 th century; however, it was the 20 th century and the rule of Reza Shah Pahlavi which brought missionary goals to fruition. Yet is was also necessary to eliminate the missionary role in order to attain the objectives of the new government.

Upon their arrival in the country the missionaries had initially worked exclusively among the Nestorians. During the early years of missionary work close ties had developed between the two. The missionaries had learned the language of the people and had taught in that language. They had also written texts dealing with the cultural heritage of the Nestorians and had used these books in the classrooms. The spoken language had been reduced to a written form easily understood by the people. Previously the only written script had been that of ancient Syriac used in the church rites and the common man had no knowledge of this language. A11 of these things which the missionaries did to bring themselves closer to the Nestorians, were at the same time 
alienating this segment from the society in which they lived. The Nestorians tended to identify more with the American missionaries than they did with their fellow Iranians. After all they were both Christians; a minority amidst an Islamic majority.

Intermittently throughout the 19 th century this reliance on the missionaries had been brought to the attention of the central government. However, no firm action was taken to alter the situation. There were occasional rebukes and warnings, but these were usually not carried out. It was to be under the rule of Reza Shah that effective legislation was enacted to eliminate this dependence upon an outside element.

Coming to power in 1921, Reza Shah's goals were centralization of authority and elimination of foreign control within the country. In order to attain his goals he found it necessary to assimilate all elements of society. The tribes were to be brought under control, the ulama's power decreased, the landowner's influence lessened, and the minority loyalties subjegated to that of the nation. To carry out such a project it was necessary to instill a sense of national pride and unity. In so doing, all other loyalties had to be put aside. The people were to consider themselves first and foremost Iranians. The Shah was quick to realize that education was the most effective means of creating a sense of national identity. However, the modern education desired was controlled by foreign elements in Iran. It would be necessary, therefore, to create a national educational system which might at first compete with the foreign schools and eventually supplant them. In the meantime, certain measures were taken to limit the work of foreign educators in the country and to 
simultaneously draw the minorities into the government's program of assimilation.

After establishing a national educational system, Reza Shah realized that government restrictions on foreign education were insufficient. He had succeeded in standardizing the texts and curriculum, requiring all instruction to be in the Persian 1anguage, and placing al1 elementary school children (grades 1-6) in government schools. By 1939, however, events necessitated complete government control of education, thereby eliminating foreign schools in Iran. Among the major considerations in the government's decision to take over all foreign schools at this time was the growing concern over Russian influence. The Russians had recently expressed a desire to establish schools in Iran. Knowing the part which the Russians had played in the revolts in northwestern Iran and believing that they still sought territorial gains, the Shah saw this request for schools as a potential means of dispersing propaganda and wished to restrict such activity. Rather than place restrictions on only one foreign nation, he felt it wiser to abolish all foreign schools in the country and thereby prevent any problems in the future.

It is clear that the closure of mission schools was an integral part of limiting foreign control in Iran. The influence which such schools had cannot be underestimated. It has already been mentioned that these schools provided not only basic education, but also values and ideas as we11. These were an important byproduct of foreign teaching. In some instances these were counter to the ideas propounded by the government in its program of unifying the nation. 
It becomes clear that school closures were necessary to attain the goals of the new government. In order to unite the nation, it was essential that education be government controlled. It was not incidental that placing it in the hands of the government also lessened foreign influence in the country. The establishment of a national education system thus served the purposes of assimilating the minorities and freeing Iran from foreign domination.

The closure of medical work in Iran also came about partially as a result of government measures. However, even prior to government restrictions the missionaries were working under short staffing conditions and the imposition of government controls only speeded up the closing process. Some American missionary doctors were helping set up medical departments at government universities and others had been asked to teach courses. They had taken part in licensing physicians and also served on boards to review medical practices. Throughout their final years in Iran they were following the advice of the first American missionary doctor to Iran, Aashe1 Grant, who advised cooperation rather than competition. They were assisting in establishing the medical facilities and training the Iranians who would take over their work among the people.

By 1940 the point had finally been reached at which the Iranian government was able to provide the necessary educational and medical services for its people. The missionary role had been absorbed by the state. Though restrictions were relaxed following the 1941 abdication of Reza Shah, the main force of the missionary work in Iran had been spent. A few remained to continue their work though no foreigners were allowed to work independent of government control. With such restrict- 
ions most felt the time had come for them to withdraw from the field and leave the work to the Iranian people. They had accomplished a great deal and could view their work as a stimulant to the progress made in Iran during the 20 th century. 
Adamiyat, Feridoun. Amir Kabir va Iran. Tehran, 1348 A.H.

Anderson, Rufus. History of the Missions of the American Board of Commissioners for Foreign Missions to the Oriental Churches. 2 vols. Boston: Congregation Publishing Society, 1892.

Antonius, George. The Arab Awakening.

Armajani, Yahya. Iran. New York: Prentiss Ha11, 1972.

Armajani, Yahya. Letter to writer dated February 17, 1973.

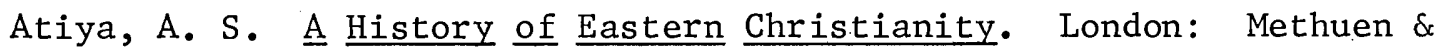
Co., Ltd., 1968 .

Attwater, Dona1d. The Christian Churches of the East. Milwaukee: Bruce Publishing Co., 1962.

Banani, Amin. The Modernization of Iran, 1921-1941. Stanford: Stanford University Press, 1961.

Barton, James. "American Education and Philanthropic Interest in the Near East." Mus1im Wor1d, Apri1 1933.

Barton, James. Christian Approach to Islam. Boston: The Pilgrim Press, 1918.

Barton, James. Story of Near East Relief (1915-1930), An Interpretation. New York: The Macmillan Co., 1930.

Barton, James L. Educationa1 Missions. Student Volunteer Movement for Foreign Missions, 1913.

Benjamin, Samuel Green Wheeler. Persia and the Persians. London: John Murray, 1887.

Birjandi, Dr. Parvin. Letter to writer dated February 23, 1973

Boyajian, Dickran H. Armenia: The Case of a Forgotten Genocide. Westwood: Educationa1 Book Crafters, 1972 .

Boyce, Annie S. "Government Education for Girls in Persia." Muslim World, July 1920.

Boyce, Arthur C. "Alborz College of Teheran and Dr. Samuel Martin Jordan, Founder and President." (mimeographed), 1954.

Brown, Arthur Judson. 100 Years: A History of the Foreign Missionary Work of the Presbyterian Church in the USA, with Some Account of Countries, Peoples and the Policies and Problems of Modern Missions. New York: Fleming H. Revell Co., 1937. 
Brown, Arthur Judson. The Foreign Missionary; An Incarnation of a World Movement. New York; Fleming H. Revell Co., 1907.

Century of Mission Work in Iran (Persia) 1834-1934. Beirut: American Press, n.d.

Cottam, Richard W. Nationalism in Iran. Pittsburgh: University of Pittsburgh Press, 1964.

"Current Topics." Mus1im Wor1d, Vo1. 3, October 1913.

"Current Topics." Muslim Wor1d, Vol. 4, Apri1 1914.

"Current Topics." Mus1im Wor1d, Vo1. 6, January 1916.

"Current Topics." Mus1im Wor1d, Vo1. 10, January 1919.

"Current Topics." Mus1im Wor1d, Vo1. 11, January 1921.

Danie1, Robert L. American Philanthropy in the Near East 1820-1960. Athens: Ohio University Press, 1970.

Day, Clarence B. Letters to writer dated February 25, 1973 and June 4, 1973.

DeNovo, John A. American Interests and Policies in the Middle East 1900-1939. Minneapolis: University of Minnesota Press, 1963.

Dodd, Edward M. How Far to the Nearest Doctor? - Stories of Medical Missions Around the World. New York: Friendship Press, 1933.

Doolittle, Jane E. Letter to writer of February 4, 1973.

Dwight, H. G. 0. Christianity in Turkey. New York, 1854.

Dwight, H. G. 0. Christianity Revived in the East. New York: Baker and Scribner, 1850 .

Earle, Edward Mead. "American Missions in the East." Foreign Affairs, VII, April 1929. .

E1der, John. History of the American Presbyterian Mission to Iran 1834-1960. Literature Committee of the Church Council of Iran, n.d.

Elder, John. Letter to writer dated January 24, 1973.

E1sbree, 01iver Wende11. The Rise of the Missionary Spirit in America 1790-1815. Williamsport: The Williamsport Printing and Binding Co., 1928 .

Entner, Marvin L. Russo-Persian Commercial Relations, 1828-1914. Gainesville: University of Florida Press, 1965. 
"Farhange No Cheguneh Dar Iran Aqaz Shood? Xedmate Roshdieh Be Ma'aref." Amuzesh va Parvaresh, XXV, n.d.

Fie1d, James A. America and the Mediterranean Wor1d 1776-1882. Princeton: Princeton University Press, 1969.

Finnie, David H. Pioneers East - The Early American Experience in the Middle East. Cambridge: Harvard University Press, 1967.

Funk, J. Arthur. "The Missionary Problem in Persia." Muslim Wor1d, X, Apri1 1920.

George Arents Research Library, Syracuse University. Letter received by writer from Librarian Manuscript, Carolyn Ann Davis dated February 26, 1973.

Goodman, Neville. "Health Services in Afghanistan, Iran and Turkey." Royal Central Asian Society Journal, LIII, June 1966.

Grabi11, Joseph. "Missionary Influence on American Relations with the Near East, 1914-1923." Muslim Wor1d, LVIII, January 1968.

Grabi11, Joseph. Protestant Diplomacy and the Near East; Missionary Influence on American Policy 1810-1927. Minneapolis: University of Minnesota Press, 1971.

Groseclose, E1gin. Introduction to Iran. New York: Oxford University Press, 1947.

Groseclose, E1gin. The Persian Journey of the Reverend Ashley Wishard and His Servant Fathi. New York: The Bobbs-Merri11 Co., 1937.

Groves, Walter A. Letter to writer dated February 5, 1973.

Gurney, F. Taylor. Letters to writer dated February 5, 1973; February 15, 1973; February 23, 1973. Cassette tape also sent to writer in March 1973.

Haddad, Robert M. Syrian Christians in Mus1im Society - An Interpretation. Princeton: Princeton University Press, 1970.

Hill, Richard. "Government and Christian Missions in the Anglo-Egyptian Sudan, 1899-1914." Middle East Studies, I (No. 2), January 1965.

Hourani, Albert (ed.). "The American Missionaries in Beirut and Butrus al-Bustani" St. Anthony's Papers, No. XVI, Carbondale: Southern I11inois University Press.

Iran Almanac, 1970.

Islami, Dr. Abdo1 H. Letter to writer dated May 2, 1973.

Janin. Rev. Pere. The Separated Eastern Churches. (trans. by Rev. Canon P. Boylan), London: Sands \& Co., 1933. 
Joseph, John. The Nestorians and Their Muslim Neighbors: A Study of Western Influence on their Relations. Princeton: Princeton University Press, 1961.

Kasravi, Ahmad. Tarikhe Mashrutiate Iran. Tehran, 1349 AH.

Kedourie, Elie. "The American University of Beirut." Middle East Studies, III (No. 1), October 1966..

Kedourie, E1ie. The Chatham House Version and Other Middle East Studies. New York: Praeger Publishers, 1970.

Langer, William L. The Diplomacy of Imperialism. New York: Alfred A. Knopf, 1960:

Latourette, Kenneth Scott. Christianity in a Revolutionary Age - The 19th Century Outside Europe: The Americas, The Pacific, Asia and Africa. New York: Harper \& Brothers, 1961.

Latourette, Kenneth Scott. The Emergence of a World Christian Community. New Haven: Yale University Press, 1949.

Latourette, Kenneth Scott. A History of the Expansion of Christianity The Great Century - Northern Africa and Asia 1800-1914. VI, New York: Harper and Brothers, 1944.

Latourette, Kenneth Scott. A History of the Expansion of Christianity Advance through Storm - 1914 and After, with Concluding Generalizations. VII, New York: Harper and Brothers, 1945.

Laurie, Thomas. Dr. Grant and the Mountain Nestorians. Boston: Gould and Lincoln, 1856.

Laurie, Thomas. Woman and Her Saviour in Persia. Boston: Gould and Lincoln, 1863.

Malek, Mrs. Iran. Letter to writer dated February 22, 1973.

Marsha11, Thomas William. Christian Missions: Their Agents, Their Method and Their Results, II, London: Burns and Lambert, 1862.

McDowe11, Sarah. "A Century of Medical Missions in Iran." unpublished work, n.d.

McDowe11, Sarah. Letters to writer dated January 29, 1973 and February $8,1973$.

Mehran, M. R. Letter to writer dated March 8, 1973.

Memorial Volume of the First Fifty Years of the American Board of Commissioners for Foreign Missions, Boston, 1862. 
Miller, William McE1wee. "Ear1y Efforts Among Mohammedians in Persia." Mus1im Wor1d, XXIII, October 1933.

Miller, William McE1wee. Ten Muslims Meet Christ. Grand Rapids: William B. Eerdsmans Publishing Co., 1969.

Mi11er, William McE1wee. Letter to writer dated February 21, 1973.

Missionary Herald, Boston, 1830-1880.

"Missionary News: Hamadan." Muslim Wor1d, II, Apri1 1912.

Missionary Review of the World, Princeton, 1878-1939.

Mode, P. G. Sourcebook and Bibliographical Guide for American Church History. Boston: J. S. Canner and Co., Inc., 1964.

Nei11, Stephen, Gerald Anderson, John Goodwin (eds.). Concise Dictionary of the Christian World Mission. New York: Abingdon Press, 1971 .

Nichols, James Hastings. History of Christianity 1650-1950, Secularization of the West. New York: Ronald Press Co., 1956.

Pahlavi, Mohammed Reza Shah. Mission for My Country. New York: McGrawHi11 Book Co., Inc., 1961.

Perkins, Justin. A Residence of Eight Years in Persia Among the Nestorian Christians. New York: M. W. Dodd, 1834.

Polk, William R. and Richard Chambers (eds.). Beginnings of Modernization in the Middle East: The Nineteenth Century. Chicago: The University of Chicago Press, 1968.

Potter, J. L. "Religious Liberty in Persia." Muslim World, III, January 1913.

Richter, Julius. A History of Protestant Missions in the Near East. New York: Fleming H. Reve11 Co., 1910.

Sadiq, Issa Khan. Modern Persia and Her Educational System. Studies of the International Institute of Teachers College. New York: Columbia University Press, 1931.

Shedd, Mary Lewis. The Measure of a Man: The Life of William Ambrose Shedd, Missionary to Persia. New York: George H. Doran, 1922.

Speer, Robert. "Christian Schools in Persia." Mus1im Wor1d, II, January 1912.

Speer, Robert E. "The Hakim Sahib" The Foreign Doctor - A Biography of Joseph Plumb Cochran, M.D. of Persia. New York: Fleming H. Reve11 Co., 1911. 
Sundberg, Vohnie. The United Missionary Library, New York. Letter to writer dated February 15, 1973.

Sutton, L. P. E1we11. Modern Iran. London: George Routledge \& Sons, Ltd., 1941.

Sykes, Mark. Dar a1-Islam - $\underline{\text { Record }}$ of a Journey Through Ten of the Asiatic Provinces of Turkey. London: Bickers \& Son, 1904.

Tibawi, A. L. American Interests in Syria 1800-1901, a Study of Educational Literary and Religious Work. Oxford: Clarendon Press, 1966.

Trevelyan, G. M. English Social History - A Survey of Six Centuries, Chaucer to Queen Victoria. London: Longmans, Green and Co., 1942.

Wagner, Dr. Moritz. Travels in Persia, Georgia and Koordistan; with Sketches of the Cossacks and the Caucasus, III, London: Hurst and B1ackett, 1856 .

Waterfield, Robin E. Christians in Persia - Assyrians, Armenians, Roman Catholics and Protestants. London; George Allen and Unwin Ltd., 1973.

Waterfield, Robin E. Letter to writer dated February 1973.

Watson, Charles R. What Is This Moslem Wor1d? New York: Friendship Press, 1937.

Wilson, Samuel Graham. Persian Life and Customs - With Scenes and Incidents of Residence and Trave1 in the Land of the Lion and the Sun. New York: Fleming H. Reve11, 1895.

Wilson, Samuel Graham. "The Russian Occupation of N. Persia." Muslim Wor1d, III, October 1913.

Wilson, W. Christy. Introducing Islam. New York: Friendship Press, 1958.

Wolff, Joseph. Wolff's Missionary Labours: Researches and Missionary Labours Among the Jews, Mohammedans and Other Sects. Philade1phia: Orrin Rogers, 1837.

Wright, Edwin M. Letter to writer dated January 28, 1973.

Wysham, William N. Letter to writer dated January 23, 1973.

Yeselson, Abraham. United States-Persian Diplomatic Relations 1883-1921. New Brunswick: Rutgers University Press, 1956.

Yoe1, William. Letter to writer dated February 26, 1973. 
Young, T. Cuyler (ed.). Near Eastern Culture and Society. "Islamic Literature: Persian".

Young, T. Cuyler. Letter to writer dated February 7, 1973. 
APPENDIX 


\section{AMERICAN MISSIONARIES TO IRAN PRIOR TO 1870}

\begin{tabular}{|c|c|c|}
\hline $\mathrm{D}=\mathrm{died}$ in service & $=$ transferred & to another \\
\hline Abbe, Burr Reeve, M.D. & $1855-1855$ & $\mathrm{~W}$ \\
\hline Abbe, Mrs. (E1izabeth Swift Nye) & $1855-1855$ & $\mathrm{~W}$ \\
\hline Ambrose, Rev. Thomas Lyford & $1858-1861$ & $\mathrm{~W}$ \\
\hline Beach, Aura Jeanette & $1860-1864$ & $\mathrm{~W}$ \\
\hline Breath, Edward (printer) & $1840-1861$ & $\mathrm{D}$ \\
\hline Breath, Mrs. (Sarah Ann Young) & $1849-1862$ & $\mathrm{~W}$ \\
\hline Cobb, Rev. Henry Nitchie & $1860-1864$ & W \\
\hline Cobb, Mrs. (Matilda Emeline Van Tandt) & $1860-1864$ & $\mathrm{~W}$ \\
\hline Crane, Rev. Edwin Ha11 & $1852-1854$ & $\mathrm{D}$ \\
\hline Crane, Mrs. (Ann Eliza Cowles) & $1852-1857$ & $\mathrm{~W}$ \\
\hline Crawford, Harriet Newe11 & $1860-1865$ & $\mathrm{~W}$ \\
\hline Fiske, Fidelia & $1843-1858$ & $\mathrm{~W}$ \\
\hline Grant, Aashe1, M. D. & $1835-1844$ & $\mathrm{D}$ \\
\hline Grant, Mrs. (Judith L. Campbe11) & $1835-1839$ & $\mathrm{D}$ \\
\hline Hinsdale, Rev. Abel Knapp & $1841-1842$ & $\mathrm{D}$ \\
\hline Hinsdale, Mrs. (Sarah Cynthia Clark) & $1841-1844$ & $\mathrm{~T}$ \\
\hline Holladay, Rev. Albert Lewis & $1837-1846$ & $\mathrm{~W}$ \\
\hline Holladay, Mrs. (Anne Yancy Minor) & $1837-1846$ & $\mathrm{~W}$ \\
\hline Jones, Rev. Willard & $1839-1845$ & $\mathrm{~W}$ \\
\hline Jones, Mrs. (Miriam Pratt) & $1839-1845$ & $\mathrm{~W}$ \\
\hline Laurie, Rev. Thomas & $1842-1844$ & $\mathrm{~T}$ \\
\hline Laurie, Mrs. (Martha Fletcher Osgood) & $1842-1843$ & $\mathrm{D}$ \\
\hline Merrick, Rev. James Lyman & $1834-1846$ & $\mathrm{~W}$ \\
\hline Merrick, Mrs. (Emma Taylor) & $1839-?$ & $\mathrm{D}$ \\
\hline Mitche11, Rev. Co1by Chew & $1841-1841$ & $\mathrm{D}$ \\
\hline Mitche11, Mrs. (E1iza A. Richards) & $1841-1841$ & $\mathrm{D}$ \\
\hline Perkins, Rev. Justin & $1833-1869$ & $\mathrm{D}$ \\
\hline Perkins, Mrs. (Charlotte Bass) & $1833-1857$ & $\mathrm{~W}$ \\
\hline Rhea, Rev. Samue1 Audley & $1851-1865$ & $\mathrm{D}$ \\
\hline Rhea, Mrs. (Martha Ann Harris 1) & $1851-1857$ & $\mathrm{D}$ \\
\hline Rhea, Mrs. (Sarah Jane Foster 2) & $1860-1869$ & $\mathrm{~W}$ \\
\hline Rice, Mary Susan & $1847-1864$ & $\mathrm{~W}$ \\
\hline Stocking, Rev. William Redfield & $1837-1854$ & $\mathrm{~W}$ \\
\hline Stocking, Mrs. (Jerusha Emily Gilbert) & $1837-1854$ & $\mathrm{~W}$ \\
\hline Stoddard, Rev. David Tappan & $1843-1857$ & $\mathrm{D}$ \\
\hline Stoddard, Mrs. (Harriet Briggs 1) & $1843-1848$ & $\mathrm{D}$ \\
\hline Stoddard, Mrs. (Sophia Dana Hazen 2) & $1851-1858$ & $\mathrm{~W}$ \\
\hline Thompson, Rev. Amherst Lord & $1860-1860$ & $\mathrm{D}$ \\
\hline Thompson, Mrs. (Esther Ely Munson) & $1860-1862$ & $\mathrm{~W}$ \\
\hline Van Norden, Thomas Langdon M.D. & $1866-1871$ & $\mathrm{~W}$ \\
\hline Van Norden, Mrs. (Mary Maitland Paterson) & 1) $1866-1871$ & $\mathrm{~W}$ \\
\hline Wright, Austin H., M.D. & $1840-1865$ & $\mathrm{D}$ \\
\hline Wright, Mrs. (Catherine A. Myers) & $1843-1867$ & $\mathrm{~W}$ \\
\hline Young, Frank Newman Henry M.D. & $1860-1863$ & W \\
\hline
\end{tabular}




\begin{tabular}{|c|c|c|c|}
\hline $\begin{array}{l}\text { AMERICAN MISSIONARIES } \\
\text { AFTER } 1870\end{array}$ & TO IRAN & & \\
\hline $\mathrm{D}=$ died in service $\mathrm{R}=$ retired & $\mathrm{T}=$ transferred & to another & field \\
\hline Ainslie, Rev. John A. & $1881-1898$ & $W$ & \\
\hline Ainslie, Mrs. (E11en Dunham) & $1881-1898$ & $\mathrm{~W}$ & \\
\hline Alexander, Edgar W. M.D. & $1882-1892$ & $\mathrm{~W}$ & \\
\hline Alexander, Mrs. & $1882-1892$ & W & \\
\hline Allen, Rev. Cady H. & $1911-1956$ & $\mathrm{R}$ & \\
\hline Al1en, Mrs. (Helen Hague 1) & $1911-1927$ & $\mathrm{D}$ & \\
\hline Allen, Mrs. (Huldah M. Bryan 2) & $1920-1928$ & $\mathrm{~W}$ & \\
\hline & $1931-1956$ & $\mathrm{R}$ & \\
\hline Allen, Rev. E1i T. & $1891-1897$ & W & \\
\hline & $1911-1923$ & $\mathrm{~W}$ & \\
\hline Allen, May Wallace & $1894-1897$ & $\mathrm{~W}$ & \\
\hline Amerman, Bertha $\mathrm{E}$. & $1916-1922$ & W & \\
\hline Armstrong, Rev. Klair L. & $1927-1941$ & W & \\
\hline Armstrong, Mrs. (Bessie G. Cunningham) & $1927-1941$ & $\mathrm{~W}$ & \\
\hline Baber, Eunice Ada R.N. & $1946-1949$ & $\mathrm{~W}$ & \\
\hline Bartlett, Cora C. & $1882-1912$ & $\mathrm{~W}$ & \\
\hline Bassett, Rev. James & $1871-1884$ & $\mathrm{~W}$ & \\
\hline Bassett, Mrs. (Abigail Wells) & $1871-1884$ & $\mathrm{~W}$ & \\
\hline Bassett, Sarah J. & $1875-1888$ & $\mathrm{~W}$ & \\
\hline Beaber, Lillie B. & $1899-1938$ & $\mathrm{R}$ & \\
\hline Bean, Bernice R.N. & $1959-$ & & \\
\hline Bentley, Rev. Livingston & $1918-1960$ & $\mathrm{R}$ & \\
\hline Bentley, Mrs. (Florence H. Miller) & $1921-1960$ & $\mathrm{R}$ & \\
\hline Benz, Gertrude E. & $1920-1952$ & $\mathrm{R}$ & \\
\hline Benz, Lauretta $\mathrm{R}$. & $1922-1925$ & $\mathrm{~W}$ & \\
\hline Bird, Frederick L. & $1916-1922$ & $\mathrm{~W}$ & \\
\hline Bird, Mrs. (Mira Sutherland) & $1913-1922$ & $\mathrm{~W}$ & \\
\hline Bird, Jackson W. & $1956-$ & & \\
\hline Bird, Mrs. (Phyllis McGeachy) & $1956-$ & & \\
\hline Blackburn, Rev. Charles S. & $1896-1905$ & $\mathrm{~W}$ & \\
\hline Blackburn, Mrs. (Amy M. Warlng) & $1896-1905$ & $\mathrm{~W}$ & \\
\hline Blair, Edward M.D. & $1925-1938$ & $\mathrm{~W}$ & \\
\hline Blair, Mrs. (Catherine R. Cooper) & $1925-1938$ & $\mathrm{~W}$ & \\
\hline Bourne, Colleen Caroline & $1949-1951$ & $\mathrm{~W}$ & \\
\hline Bowers, Rev. LeRoy M.D. & $1958-$ & & \\
\hline Bowers, Mrs. (Jean Farrish) & $1958-$ & & \\
\hline Bowman, Lew $\mathrm{W}$ & $1933-1934$ & $\mathrm{~W}$ & \\
\hline Bowman, Mrs. (Mariam B. Richardson) & $1933-1934$ & $\mathrm{~W}$ & \\
\hline Boyce, Arthur C. & $1915-1949$ & $\mathrm{R}$ & \\
\hline Boyce, Mrs. (Annie W. Stocking) & $1906-1949$ & $\mathrm{R}$ & \\
\hline Bradford, Flora L. & $1907-1908$ & $\mathrm{~W}$ & \\
\hline Bradford, Mary Elizabeth M.D. & $1888-1909$ & $\mathrm{~W}$ & \\
\hline Brann, Marolyn R.N. & $1959-$ & & \\
\hline Brashear, Rev. Turner G. & $1890-1899$ & $\mathrm{~W}$ & \\
\hline Brashear, Mrs. (Annie Hewins) & $1890-1899$ & $\mathrm{~W}$ & \\
\hline Brinkman, Harry M.D. & $1931-1938$ & $\mathrm{~W}$ & \\
\hline Brinkman, Mrs. (Adriana Van Lopik) & $1931-1938$ & $\mathrm{~W}$ & \\
\hline
\end{tabular}


Browning, Rev. George L.

Browning, Mrs. (Edna B. Guild)

Bryant, Emily J.

Bucher, Rev. Robert Y.

Bucher, Mrs. (Carolyn M. Wilson)

Bullert, Martha

Burgess, Mary E.

Bussdicker, Russe11 D. M.D.

Bussdicker, Mrs. (Blanche Gillis)

Carey, Agnes

Carver, Lynda (Iraq 1946)

Chambers, Estella M.

Chase, Leree Stella

Childs, Katherine R.N.

Clark, Mary A.

1923-1952 D

1918-1957 R

$1872-1873 \quad W$

1933-

1933-

1938-1940 W

1915-1930 W

1922-1958 R

1922-1958 R

1880-1884 W

$1959-$

1936-1950

$1923-$

Coan, Elizabeth Veech

Coan, Rev. Frederick G.

1925-1930 W

1880-1885 W

1892-1898 W

1914-1919 W

1885-1924 R

Coan, Mrs. (Ida Speer)

1885-1924 R

Coan, Rev. George W.

Coans, Mrs. (Sarah Power)

Cochran, Dorothy Anne R.N.

Cochran, Emma G.

Cochran, Katherine

Cochran, Rev. Joseph G.

Cochran, Mrs. (Deborah Plumb)

Cochran, Joseph P. M.D.

Cochran, Mrs. (Katharine Hale)

Cochran, Mrs. (Bertha H. McConaughy 2)

1849-1874 W

1849-1874 W

1945-1947 W

1885-1888 W

1871-1875 W

1847-1871 D

1847-1871 W

1878-1905 D

1878-1895.D

1900-1907 W

1909-1932 W

1920-1958 R

1920-1958 R

$1912-1920 \quad W$

1929-1932 D

1913-1920 W

1929-1932 W

Cowden, Margaret L.

1915-1949 R

Crothers, Rev. James C.

1917-1921 W

Dean, Nettie J.

1860-1894 W

Degner, Emma A. R.N.

1899-1904 W

Demuth, Margaret A.

DeWitt, Rev. Eugene $\mathrm{K}$.

DeWitt, Mrs. (EImina Titsworth)

Dillener, Rev. LeRoy Y.

1945-1959 R

1895-1900 W

1911-1915 W

1911-1915 W

1920-1925 W

Dillener, Mrs. (Emily Hense1)

1920-1925

1916-1925

1915-1940 T

Donaldson, Rev. Dwight M.

Donaldson, Mr. (Jean G. Brinton)

1914-1914 D

Donaldson, Rev. Dwight M.

1914-1940 T

Doolittle, Jane E.

1926-

Douglas, Rev. Charles A.

1901-1918 D

Douglas, Mrs. (Eva L. Ba11is)

1902-1919 W 
Dyson, Burton M.D.

1950-1956 W

Dyson, Mrs. (Elizabeth Updegraff)

$1950-1956$

Easton, Rev. Peter Z.

1873-1879 W

Easton, Mrs. (Maria E. Burnham)

Eaton, Robert M. M.D.

1873-1879 W

Eaton, Mrs. (Miriam Adams)

$1959-$

Elder, Rev. John

E1der, Mrs. (Ruth Roche)

E11is, Wilder P. M.D.

Ellis, Mrs. (Jessie L. Lee)

Enderson, Anna E.

Esselstyn, Rev. Lewis F.

Esse1styn, Mrs. (Mary Huston)

Euwer, Rev. Norman L.

Euwer, Mrs. (Myrtle B. Campbe11)

Field, Clara H. M.D.

$1959-$

1922-

$1922-$

1915-1938 W

1915-1938 W

1931-1956 R

1887-1918 D

1887-1918 W

1901-1910 W

1901-1910 W

1905-1909 W

1920-1951 W

$1960-$

Fisher, Mrs. (Franke Sheddon)

1920-1951 W

Fisher, Faye

$1960-$

F1eming, Mary R. M.D.

1915-1918 W

1915-1920 W

1905-1948 D

$1912-1946 \quad \mathrm{D}$

Frame, Mrs. (Grace J. Murray 1)

1929-1948 W

Frame, Mrs. (Adelaide Kibbe 2)

1947-1952 W

Frame, Mrs . (Dorothy Anderson)

1947-1952 W

Frey, Charles L.

Frey, Mrs. (Ethel Burrows)

$1957-$

$1957-$

Fulton, Janet S. R.N.

1931-1956 W

Fung, Sherman B.

$1954-$

Funk, John A M.D.

Funk, Mrs. (Susanna S. Leinbach)

1902-1939 D

1891-1939 R

Gardner, Mary

1913-1944 R

Gernhardt, Lucinda

1953-1958 R

Gifford, Rev. Burt S.

Gifford, Mrs. (Emma L. Campbe11)

1913-1945 D

1913-1949 R

1917-1941 T

1889-1892 W

Green, Mary Ward

1925-1941 W

Groves, Rev. Walter A.

Groves, Mrs. (Estelle Crawford)

1925-1941 W

Gurney, Frederick T.

1926-1942 W

Gurney, Mrs. (Henrietta A. Pritchard)

1926-1942 W

1923-1935 W

Hancock, Rev. William P.

1923-1935 W

Hancock, Mrs. (Kathleen G. Ballinger

1895-1897 T

Hansen, Car 1 C. M.D.

Hansen, Mrs. (Lillian D. Reinhart)

1893-1897 T

Hargrave, Arthur A.

Hargrave, Mrs. (Marion J. Moore)

1883-1887 W

Harman, Ruth E.

1884-1887 W

1931-1936 W

Harvey, E. Mary R.N. 
Hawkes, Rev. James W.

Hawkes, Mrs. (Sarah B. Sherwood)

1880-1932 D

Hoffman, Rolla E. M.D.

1883-1919 D

Hoffman, Mrs. (Helen Easton 1)

1915-1957 R

1920-1949 D

Hoffman, Mrs. (Adelaide Kibbe 2)

1950-1957 R

Holliday, Margaret Y.

Hollingsworth, Stanely

Holmes, Ada C.

Holmes, George W. M.D.

Holmes, Mrs. (E1iza A. Wisner 1)

Holmes, Mrs. (Lucy S. Hale M.D. 2)

1883-1920 D

1957 -

1905-1917 W

1874-1899 W

$1874-1890 \quad \mathrm{D}$

1892-1899 W

1947-1950 W

1947-1950 W

Hopper, Mrs. (Mollie Brown)

$1953-$

Hunter, Adeline

Hulac, Rev. Charles Rovin

Hulac, Mrs. (Jeanette Retschlag)

1889-1892 W

1946-1950 W

1946-1950 W

Huntwork, Bruce M.D.

$1958-$

Huntwork, Mrs. (Billie Blakely)

$1957-$

Hutchison, Rev. Ralph C.

1925-1931 W

Hutchison, Mrs. (Harriet S. Thompson)

1925-1931 W

Irvine, John Richard

Irvine, Mrs. (Mary Ann Cornwe11)

$1951-$

$1951-$

Irwin, Rev. John Mark

1932-

Irwin, Mrs. (Ruth Hoffman)

1932-

Jessup, Rev. Frederick N.

1903-1919 D

Jessup, Mrs. (Helen T. Grove)

1910-1931 W

Jewett, Mary

Johnson, Rev, Lewis M.

1871-1907 W

Johnson, Mrs. (Margaret Bailey)

$1959-$

1959-

Johnson, Mary C.

1917-1957 R

Johnson, Rev. R. Park

Johnson, Mrs. (Alice Eaton)

1939-1940 W

1939-1940 W

Jones, Jeanette R.N.

Jordan, Rev. Samue1 M.

Jordan, Mrs. (Mary W. Park)

Keasling, James E. M.D.

1920-1933 W

1898-1941 R

1898-1941 R

Keasling, Mrs. (Marjarie Ellen Lawrence) 1959-

Keller, Murie1 R.N.

1956-1958 W

Klerekoper, Rev. Frederick George

1945-1.951 W

Klerekoper, Mrs. (Anna M. Bruen)

Knecht, Rev. Glen

Knecht, Mrs. (Betty Jane Greenwald)

1945-1951 W

Labaree, Rev. Benjamin

Labaree, Mrs. (Elizabeth E. Woods)

Labaree, Rev. Benjamin W.

Labaree, Mrs. (Mary A. Schauffler)

Labaree, Rev. Robert M.

$1958-$

$1958-$

1860-1906 D

1860-1898 D

1893-1904 D

1893-1905 W

1904-1916 W

Labaree, Mrs. (Mary Fleming)

1904-1916 W

Lamme, Charles W. M.D.

1911-1919 W

1920-1950 R

Lamme, Mrs. (Jessie C. Garman)

1913-1950 R 
Lamme, Edith D.

$1906-1946$

Landrum, Rev. Dallas

Landrum, Mrs. (Flora Miller)

$1951-1959$

1951-1959

Lanning, Roy

1953-1959

Lanning, Mrs. (Wilhelmina E. Mitray)

$1953-1959$

Lawrence, E1isa T.

Lawrence, Mrs. (Jessie C. Wilson)

Lichtwardt, Hartman A. M.D. Rev.

Lichtwardt, Mrs. (Hilda M. Tozier)

MacDonald, Helen

McCampbe11, Letitia $\mathrm{H}$.

McCómb, Judith H.

McCrackin, Rev. Maurice F.

McDowe11, Rev. Edmund W.

McDowe11, Mrs. Edmund W. (1)

McDowe11, Mrs. (Mary Coe 2)

McDowe11, Mrs. (Margaret W. Dean 3)

McDowe11, Philip C. M.D.

McDowe11, Mrs. (Sarah E. Wright)

McKinney, Georgia L.

McLean, Jennie F.

McMillan, Rev. Ernest Lomex

McMi1lan, Mrs. (June D. Boa1)

McNair, Thomas

McNair, Mrs. (Eleanor Engeman)

1902-1919

1892-1919

1919-1945

1919-1945

1954-1957

1891-1899

$1925-1952$

$1930-1935$

$1887-1897$

$1902-1922$

$1887-1897$

1902-1915

1918-1922

1918-1944

1918-1944

1954-1960

1920-1949

1892-1898

1945-1952

1956-1959

1945-1952

1956-1959

1948-1953

1949-1953

1927-1934

1921-1934

1921-1934

1930-1934

1887-1896

1887-1896

1892-1900

1888-1897

1891-1909

$1919-$

1925-

1882-1917 D

1886-1905 D

1885-1889 W

1926-1934 W

1926-1934 W

1910-1954 R

1910-1954 R

$1943-$

1943-

1937-1940 W

1911-1920 W

1923-1931 W 
Murray, Mrs. (Grace M. Sma11ey)

1911-1920

1923-1931 W

Murray, Florence E.

Murray, Thomas A. M.D.

Murray, Mrs. (Nancy Lounsbury)

1913-1946 R

1946-

$1946-$

Nelson, Mabel

Nicholson, E11en D.

Norem, Walter M.D.

Norem, Mrs. (Katherine Morrows)

Oldfather, Rev. Jeremiah M.

Oldfather, Mrs. (Felicia N. Rice)

1922-1938 W

19.24-1955 R

1939-1947 W

1939-1947 W

1872-1891 W

1872-1891 W

Orcutt, Edna E. M.D.

Packard, Harry P. M.D.

Packard, Mrs. (Julia F. Bayley 1)

1911-1914 D

1906-1944 R

1906-1924 D

Packard, Mrs. (Edna J. Wells 2)

1916-1944 R

Palmer, Mar jorie $\mathrm{H}$.

1928-1933 W

Payne, Jo Denny

Payne, Mrs. (Grace E. Visher)

1922-1956

1922-1956

Pease, Harriet B.

Pease, Wilma E. R.N.

Peet, Gertrude

Peters, Thomas L

Phraner, Caroline

Pittman, Rev. Charles R.

Pittman, Mrs. (Lucille Drake)

Platt, Joan

Plummer, Louisa G.

Poage, Annie E.

Port, John C1inton

Port, Mrs. Ella Mae Hyde

Porter, Dorothy M.D.

Porter, Rev. Thomas J.

Porter, Mrs. (Jessie MacDonald)

Potter, Rev. Joseph L.

Potter, Mrs. (Harriet Riggs)

Pryor, Rev. Robert

Pryor, Mrs. (Ethe1 Burrows)

$1921-1957$

$1924-1960$

1917-1929

1921-1925 W

1956-

1900-1941 R

1902-1941 R

1952-1959 W

1932-1935 W

$1875-1880 \quad W$

1948-1955 W

1948-1955 W

$1957-$

1884-1886 W

1884-1886 W

1874-1913 W

1878-1913 W

$1958-$

$1958-$

$1927-$

$1950-$

Rice, Homer M.D.

Rice, Mrs.. (Charlotte L. Means)

$1950-$

Rider, Rev. Wm. Morrison Jr.

1945-1951 W

Rider, Mrs. (Marguerite Powers)

1945-1951 W

Rieben, Hubert $\mathrm{E}$.

Rieben, Mrs. (Berthe Musy)

1936-1954 R

1936-1954 R

Roberts, Emma

1887-1889 W

Rogers, Rev. James E.

$1882-1885 \quad W$

Rogers, Mrs. James

1882-1885 W

Russe11, Grace G.

1891-1900 W

St. Pierre, Rev. Edward W.

1887-1895 W

St. Pierre, Mrs.

1887-1895 W

Schenck, Anna

1877-1897 W

Schoebel, Leonore R.

1910-1918 
Schuler, Rev. Henry C.

1899-1945 R

Schuler, Mrs. (Annie G. Dale 1).

1885-1922 D

Schuler, Mrs. (Lillian B. McHenry 2)

1920-1945 R

Schneider, Arnold J. M.D.

1949-1959 W

Schneider, Mrs. (Lois Bosworth)

1949-1959 W

Scott, Clement

Scott, Rev. David

1959-

Scott, Mrs. David

Scott, Fern R.N.

1877-1879 W

1877-1889 W

Scott, Gordon W. M.D.

Scott, Mrs. (Lola Madeline Bowman)

1956-

$1959-$

$1959-$

Self, Charlotte R.N.

1956-

Seto, Rev. Paul S.

Seto, Mrs. (Genevieve Reynolds)

Sharpe, Wesley

Sharpe, Mrs. (Yola May De Grasse)

1944-1953 T

1944-1953 T

1958-1960 W

1958-1960 W

1913-1918 W

1859-1895 D

Shedd, Rev. John H.

1859-1896 W

Shedd, Mrs. (Sarah Jane Dawes)

1921-1929 W

Shedd, Rev. Paul B.

1921-1929 W

1892-1918 D

Shedd, Rev. William A.

Shedd, Mrs. (Adela L. Myers 1)

1894-1901 D

1899-1915 D

1903-1933 W

1922-1929 W

1922-1929 W

1939-1940 W

1903-1912 W

1950-1957 W

1921-1928 W

$1960-$

1952-

1889-1923 W

1902-1924 W

1900-1922 D

1919-1941 T

1919-1941 T

1900-1916 W

1908-1916 W

$1956-$

$1947-$

$1947-$

1871-1880 W

1871-1872 D

1868-1880 W

1951-1955 W

1951-1955 W

1930-1949 D

1919-1933 W

1881-1891 W

1881-1891 W

1884-1898 W 
Van Duzee, Mary $\mathrm{K}$.

$1875-1914$

Van Hook, widow James P. (Loretta Turner)

$1876-1894$

$1902-1916$

Van Norden, Rev. Thomas L. M.D.

1866-1873

Van Norden, Mrs. (Mary M. Paterson)

$1866-1873$

Vanneman, William S. M.D.

Vanneman, Mrs. (Marguerite A. Fox)

$1890-1933$

1890-1933

Wallace, Rev. Donald Ewing

1945-1952

Wallace, Mrs. (Lois Watson)

Wallstrom, Ira C. M.D.

Wallstrom, Mrs. (Doris Elaine Rylander)

1945-1952

$1955-$

$1955-$

Ward, Rev. Samue1 L.

Ward, Mrs. (Irene Briggs)

$1876-1897$

$1876-1897$

Ward, Vera R.N.

Watson, Rev. John A.

Watson, Mrs. (Inez C. Tornquist)

Watson, Rev. John G.

Watson, Mrs. (Jessia A. Rood)

Wheeler, Helen R.N.

$1958-$

$1923-1958$

$1923-1958$

1888-1902

$1888-1902$

1951-1956

Whipple, Rev. William L.

Whipple, Mrs. (Mary A11en)

$1872-1879$

1899-1901

1872-1879 W

Wilson, Rev. Frederick R.

$1950-$

Wilson, Mrs. (E1izabeth Saint)

$1950-$

Wilson, Rev. Ivan 0 .

Wils on, Mrs. (Margaret K. Bussdicker)

$1916-1934$

1920-1934

1919-1941

Wilson, Mrs. (Fern Wilson)

Wilson, Rev. Samuel G.

Wilson, Mrs. (Annie D. Rhea)

Winkelman, Gertrude R.N.

Wishard; John G. M.D.

Wishard, Mrs. (Annabette Bryan 1)

1919-1941

1880-1916

$1886-1916$

$1941-$

1889-1899

1903-1910

1893-1899

1903-1910

1927-1956

1947-

$1946-$

1921-1938

1928-1938

1878-1911

1878-1879

1885-1890

1892-1911

1927-1933

1927-1933

1920-1938

1920-1938

1958-1959

1927-1938

1920-1938

1927-1936

1923-1936

W

W

W

W

W

D

R

W

W

W

W

$\mathrm{R}$

$\mathrm{R}$

W

W

W

W

W

W

W

W

W

D

W

$\mathrm{W}$

W

D

W

D

W

W

W

D

D

W

W

W

W

W

W

W

W

W

W 
Zoeckler, Frances Louise M.D.

Zoeckler, Rev. George F.

Zoeckler, Mrs. (Mary D. Allen M.D.)

The above listing was obtained from History of the American Presbyterian Mission to Iran 1834-1960 by Rev. John E1der, pp. 98-107. 
This list does not claim to be exhaustive, yet it indicates the number of outstanding mission school graduates holding prominent positions in Iran.

Dr. H. K. Afshar

Sultan Mohammad Ameri

Ali Amini

Majid Amir-Ebrahami

Dr. Yahya Armajani

Dr. Soghra Azarmi

Agha Khan Bakhtiar

Dr. Bakhtiari

Mirza Baghir Khan

Dr. Amir Birjandi

Dr. Parvin Birjandi

Sadeq Chubak

Abdul Hassan Ebtehaj
Director of the Institute of Geophysics of Tehran University

Assistant to the first U.S. Finance Mission to Iran and Chief Interpreter

Ambassador to U.S. and prominent in government

Prominent corporation lawyer helpful to U.S.

Ph.D. and B.D. from Princeton University and Seminary, taught at Alborz College in Iran and now Head of History Department at Macalaster College in St. Paul, Minnesota

Prominent physician, specialist in cancer and psychosomatic medicine

Bank president, cabinet minister, senator

Prominent physician in Iran

Operated newspaper "Ankabut" which advocated liberal ideas

Educationalist, Vice-Minister of Education, organizer and head of Sepah Danesh (Literacy Corps)

Prominent psychiatrist, now head of the department in a U.S. hospital in New Jersey, formerly Dean of Women at Tehran University

Novelist and short story writer

Head of Bank Meli during WWI, Head of Plan Organization in late $1950^{\prime} \mathrm{s}$, now Chairman of the Board of the Iranian Bank (associated with 1st National City Bank of New York, graduate of Rasht Boys' School 
Mrs. Neyere Ebtahaj-Samii

Dr. Abbas Ekrami

Abolbashar Farmanfarmaian

Dr. Hafez Farmanfarmaian

Khodad Farmanfarmaian

Miss Sattar Farmanfarmaian

Abo1 Ghassem

Mohammad Goudarzi

Ali Ashghar Hekmat

Abbas Aryanpur Kashani

Mehdi Kashfi

Mohsen Lak

Yonaton Marzeki

Nasratollah Montasser

Majid Movaghar

Ali Movaseghi
One of first women members of Majlis, representative from Rasht, Graduate of Rasht High School and Sage College for Women

School superintendent in Tehran

Prominent lawyer and builder

Professor at Tehran University, now teaching at University of Texas

Governor of the Bank Meli and prominent economist

Organized Social Service School which was incorporated into Tehran University

Prominent editor, governor of Isfahan, now in exile

High ranking officer of the Ministry of Foreign Affairs and Ambassador in many posts

Long time Minister of Education, Senator and organizer and president of a university teaching foreign languages

President of government College of Translation

Wealthy contractor and builder

Wealthy corporation lawyer and businessman

District manager of National Iranian Oil Co., Christian preacher, prominent leader and officer of the Evangelical Church of Iran

Second ranking Iranian in former Ang1oIranian Oil Co., later Mayor of Tehran

Prominent editor, founder of charitable organization

Former Minister is now with Iranian Embassy in U.S., Director of Administration in Iranian Ministry of Foreign Affairs 
Sadeq Naraghi

Dr. Zaven Nercessian

Dr. Sa'ed

Ashot Saghatellian

Allahyar Saleh

Ali Pasha Saleh

Dr. Jehan Shah Saleh

Col. Mohammad Saleh

Dr. Rezazadeh Shafagh

Dr. Shahbahman Shahrokh

Mirat As-Sultan

Dr Hasan Taqizadeh

Varjavand, Dr. Fereidoun

Dr. Lotfi Zadeh
Prominent contractor building roads and airports

Former Chief Medical Officer of the NIOC now prominent in private practice

Christian physician in Hamadan

Manager of Foreign Trade Bank of Iran (associated with Bank of America), Graduate of Rasht Boys' School

Cabinet Minister, Ambassador to U.S.

Ranking Iranian in U.S. Embassy for 30 years, professor at Tehran University, several times refused to become Minister of Education, prominent gynecologist

Dean of Medical School of Tehran University, Chancellor of Tehran University, Minister of Health, Minister of Education (honorary degrees from Syracuse and Vienna Universities)

Military Attache at Embassy of Iran in Washington

Was professor of Iranian literature \& philosophy at University of Tehran and a member of Senate, served under Howard Baskerville (missionary) during Constitutional Revolution, Graduate of Tabriz Memorial School

Prominent biologist, taught at UC Berkeley

Hospital administrator at Tehran Hospital

Constitutionalist leader, Senator, Representative to League of Nations, President of National Assemblies

Prominent obstetrician with his own hospital in Tehran

Brilliant scientist, now at UC Berkeley, often lecturing abroad 
Mrs. Ozra Ziai

Dr. Mahmoud Ziai
Prominent in Red Lion and Sun (Iranian Red Cross) and Social Service

Chairman of Board of Damavand College in Tehran, prominent physician 
PARTIAL LISTING OF FACULTY OF ALBORZ COLLEGE

Samuel Martin Jordan

Arthur Clifton Boyce

Frederick L. Bird

William Norris Wysham

Ra1ph Cooper Hutchison

Wa1ter Alexander Groves

James H. Hil1

George W. Brainerd

S. Leroy Rambo

William C. McNeill

Edward S. Kennedy

Arthur C. Haver1y

Henri Behoteguy, Jr.

Tony Mullen

Robert Lisle Steiner

F. Taylor Gurney

Elgin Sherk

Edgar Houghton

Kelley Tucker

Albert G. Edwards

Charles Hoffman

Felix Howland

Thos. L. Peters
President \& Professor of History and Social Sciences

Vice President, Professor of Education and Psychology

Professor of English

Professor of Religion and Sacred Literature

Dean and Professor of Religion and Philosophy

Dean and Professor of Philosophy and Ethics

Instructor in Business

Instructor in Biology

Instructor in Physica1 Education

Instructor in Physics and Chemistry

Instructor in Mathematics

Instructor in English

Instructor in English

Instructor of English

Acting Professor of Commerce

Professor of Chemistry

Y. M. C. A.

English

Physical Education

English

Biology

Mathematics

English 
Hugh McCarol1

George W. Dean

James Gibbons

Howard Benfield

Arthur Scott

James H. McDonough

Herrick Black Young

John McAfee

E. Hubert Rieben

Andre Perrinjaquet

Maurice Beguin

B. Carapet Hagopian

Mirza Gholam Reza Khoshneveese

Dr. Rezazadeh Shafaq

Dr. Yahya Armajani

Mohammad Hassan Farhi

M. Ahmad Khan Nakhosteen

Ashot Arakelian

B. Tirdad Barseghian

Mansur Zandi

Nicolas Chaconas

M. Khali1 Sootoodeh
Business Methods

Business

Physical Education

Stenography

English

Biology

Professor of English Literature and Director of Resident Students

English

French and Geology

French

French

Emeritus Instructor of English

Persian Writing

Persian Philosophy and Literature

Religious Education

Persian and Arabic

Persian and Arabic

English

Bursar

Mathematics

Assistant Registrar

Elementary School

Above listing from Dr. A. C. Boyce's mimeographed paper entitled "Alborz College of Teheran and Dr. Samue1 Martin Jordan, Founder and President", (unpub1ished, 1954), pp. 11, 20-21. 